\title{
Assessment of suspended sediment discharge in the Purus River basin, Brazil
}

\section{Marcelo Latuf \& Eufran Amaral}

To cite this article: Marcelo Latuf \& Eufran Amaral (2016) Assessment of suspended sediment discharge in the Purus River basin, Brazil, International Journal of River Basin Management, 14:4, 413-429, DOI: 10.1080/15715124.2016.1215322

To link to this article: http://dx.doi.org/10.1080/15715124.2016.1215322

Accepted author version posted online: 03

Aug 2016.

Published online: 23 Aug 2016.

Submit your article to this journal $₫$

山 Article views: 67

View related articles $₫$

View Crossmark data $\asymp$ 


\title{
RESEARCH PAPER
}

\section{Assessment of suspended sediment discharge in the Purus River basin, Brazil}

\author{
Marcelo Latuf ${ }^{\mathrm{a}}$ and Eufran Amaral ${ }^{\mathrm{b}}$

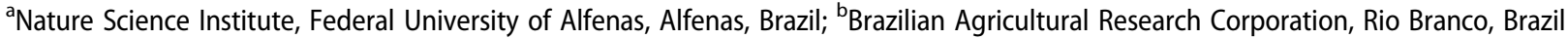

\begin{abstract}
Having a river basin as the study site, it is of fundamental importance to comprehend the sediment dynamics of river systems, in order to diagnose and understand them, aiming to carry out predictions. The observance of the sediment supply carried by the river systems is related to the erosion, transport and deposition, through rainfall and dynamic land use and cover in hillside environments. The Purus River basin is part of this context, the study area of this paper and it is located in the Amazon biome. This study aims to start the first steps to understand the suspended sediment dynamics of that basin, because of its expressive environmental variations. For this purpose was considered the sediment present in the river systems as an indicator which can be understood and used in order to support soil and water conservation measures in the Purus River basin, distinguishing the natural dynamics and anthropogenic dynamics. Thus, this study has the objective of evaluating the suspended sediments discharge in the Purus River basin, in order to collaborate with action planning and watershed management, with the objective of generating knowledge about the suspended sediment dynamics of that spring.
\end{abstract}

\section{ARTICLE HISTORY}

Received 6 November 2015

Accepted 17 July 2016

\section{KEYWORDS}

Hydrossedimentology; Brazilian Amazon region; rating curves; deforestation

\section{Introduction}

Any research project or scientific research, either with primary or secondary data, carried out in the Amazon region is, undoubtedly, a major challenge. The challenge falls under various scientific research stages and aspects, since the data collection is done, in situ, in an environment of difficult access. Not only because of the fact that the landscape sometimes is flooded, but also due to the lack of movement routes that are faster, where the distances seem to have no end; there is also the data processing from few and irregular sampling.

The land access to which we are accustomed (roads and railways) are scarce in this region of the planet and its construction and maintenance is expensive and takes time. An example is the BR-364 road, which requires decades to be completed in the Acre State, not due to the government inaction, but because of the various difficulties faced in a hostile environment.

The difficulty lies in the time that each individual has, because the time depends on the Amazon water cycle, the rainy and dry season variations and the depth of the rivers which are the real Amazon road. Life has another speed, not the speed at which we are accustomed.

As a result, it was considered by many, not long time ago, as an unexplored region, where there was nothing, where you could do everything. They forgot or, in other words, subjugated native and local people. Thus, it was tried to transplant a land use model that was not suited to the local and regional characteristics, a model based on agrarian relationship and agricultural exporter, coming from the south-central Brazil.

This model has brought agrarian conflicts that persist to the present, as well as native forests deforestation to make way for pastures and temporary crop plantations for export purposes.

With the growing deforestation in recent decades, the eyes of the world turned to the Amazon. Thus, international pressure began to be felt by government agencies of the various spheres of power. Deforestation is now a priority issue to government planning meetings, as well as the development of combat and control strategies by the Brazilian government.

However, the forest hides a bit thick substrate and low in nutrients, and with the deforestation there is a change in various elements cycles, such as nitrogen, carbon, among others, and what was forest quickly turns into degraded area, because there is no expressive technical support to preserve such biome as necessary.

Years went by, and associated with that context, there is a rising demand for natural resources to the Brazilian economic and population growth in the region (e.g. demand for water). However, with the increasing deforestation (even at a slower pace), an increase of degraded areas and poorly managed, and population demand, can bring significant challenges to public administrations in the near future. There are even researchers who add to this situation the issues related to climate change.

The Purus River basin is studied in this paper in order to give the first steps to understand suspended sediment dynamics of that basin because of its expressive environmental variations. For this purpose, it was considered the sediment present in the river systems as an indicator which can be translated and used in order to support soil and water conservation measures in the Purus River basin, distinguishing the natural dynamics to the anthropogenic dynamics.

Thus, this study has the objective of evaluating the suspended sediment discharge (SSD) in the Purus River basin, in order to collaborate with action planning and watershed management, with the purpose of generating knowledge about the suspended sediment of that spring.

\section{Study site}

Located on the western Amazon, the Purus River basin (Figure 1) is configured as one of the main tributaries of the right bank Solimões river, being part of the Latin American context of planning and management water and water 


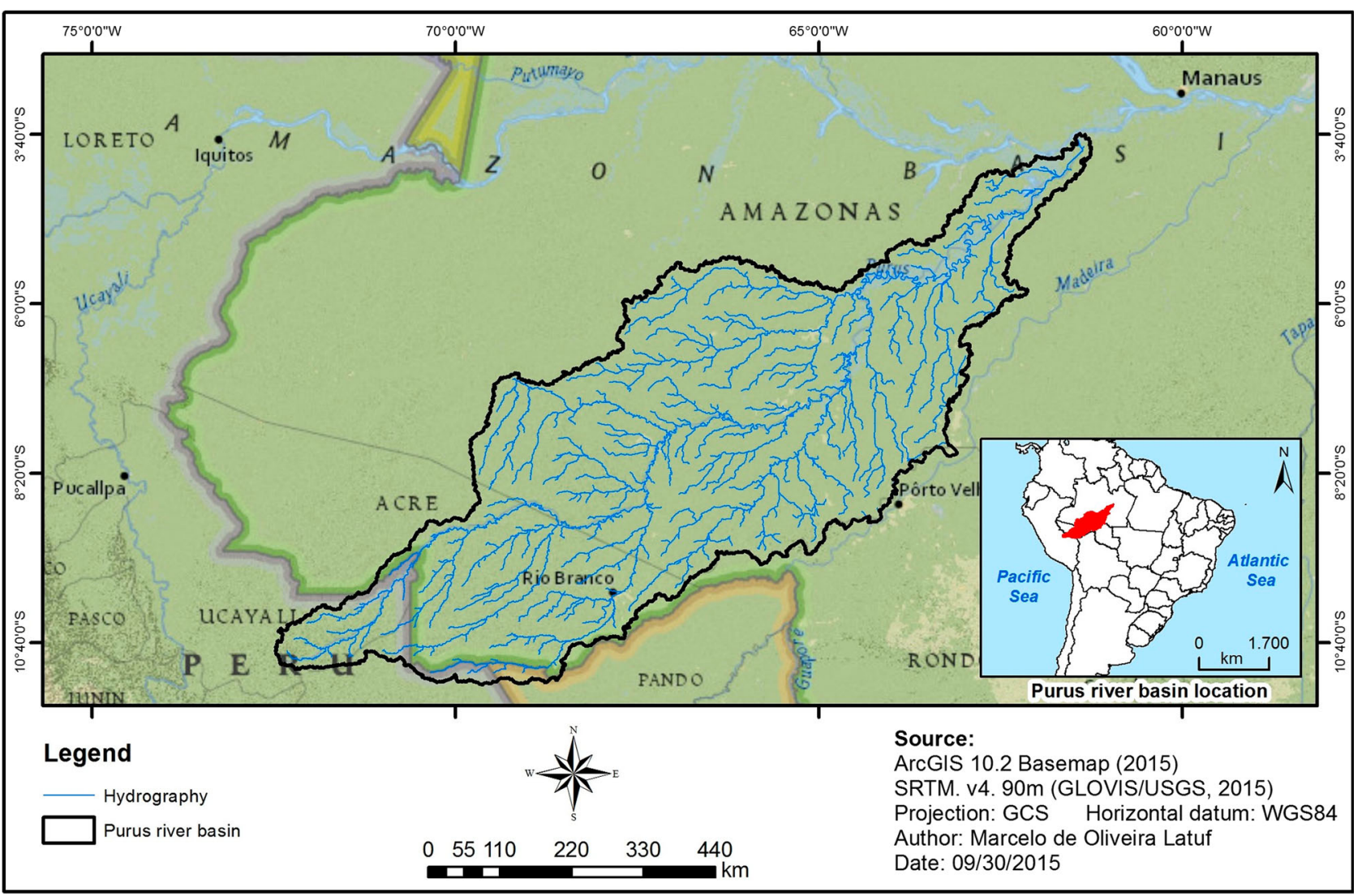

Figure 1. Purus River basin location, Brazil/Peru/Bolivia.

resources in border areas between Brazil, Peru and Bolivia. The basin has territories in the Departments of Ucayali (Peru) and Pando (Bolivia) as well as in the Brazilian Acre and Amazonas States.

Waters originated from Bolivia enter the Acre State, but mainly from Peru, through the rivers basin of Acre, Laco, Purus, Envira, Tarauacá and Jurua, feeding the Juruá and Purus Rivers watersheds, major tributaries of the right bank of the Amazon River basin. Also, the Purus River basin, through the Purus and Acre Rivers, is the navigable route between Rio Branco/AC and Manaus/AM (Acre 2006).

Since its recognition, the English explorer William Chandless in one of his articles about the Purus River (Ascent of the River Purûs), published by the Journal of Royal Geographical Society of London, reported a sharp observation of flooded events, as well the flow and rise of plantation areas description used by inhabitants and natives, associated with changes in water levels.

Annual flows variations in the Purus River and some of its tributaries highlighted by Chandless (1866) are associated with a natural climate prevailing system dynamics in the basin, with two distinct periods related to the spatial and temporal rainfall distribution and to the geological pedogeomorphic basin's characteristics, reflecting seasonal variations in the hydrological behaviour of its annual daily flow (Acre 2006, Latuf 2011).

With an area of approximately $377,100 \mathrm{~km}^{2}$, the Purus River basin has channels in dendritic pattern, but there is a structural control drainage in some places, mainly associated with changes in lithology and geomorphology. The long period mean flow near the mouth of the river is $14,465 \mathrm{~m}^{3} \mathrm{~s}^{-1}$ for the hydrometric station Arumã-Jusante (code: 13962000).

The basin has a certain geological homogeneity, owing to the fact that the Solimões Formation is a significant part of the basin ( $75 \%$, Figure 2$)$. Latrubesse and Ramanell (1994) admitted that the Solimões Formation has a single continuous depositional cycle, through giant fans, during the Upper Miocene and the Pliocene (time correlated with the abundant and varied mammals fauna) (Acre 2006).

According to Amaral's data (2007), the Solimões Formation started with the Amazon Lake formation, hypothesis defended by Frailey et al. (1988) 'it reinforces the theory according to which, the geological, soil and biological conditions can only be well understood from a landscape evolution model'.

In this lake, there was a gradual sediment deposition, forming a laminar structure to this geological formation, which hinders the movement of groundwater, diminishing significantly its storage.

The basin climate, according to the Köppen climate classification, is: Af, Am, Aw, CFB and CwB (Peel et al. 2007). Also, to the largest areas are given the Tropical Equatorial (Af) and Climate of Monsoon (Am) classification.

The climate type Af is characterized by the absence of a dry season, with a temperature mean of the coldest month exceeding $18^{\circ} \mathrm{C}$ and rainfall greater than the annual potential evapotranspiration. Furthermore, the climate type Am is characterized by annual rainfall exceeding $1500 \mathrm{~mm}$ and precipitation of the driest month less than $60 \mathrm{~mm}$.

It is essential to highlight the Alto Purus region, which is characterized by the predominance of the climate type Aw, with two distinct seasons (wet and dry), characterized by the average duration of 4-5 months with a dry season.

The average annual precipitation in the basin is between $1800 \mathrm{~mm}$ and $2400 \mathrm{~mm}$, according to the analysis of the Climatological Normal isohyets, provided by the National Institute of Meteorology (Ramos et al. 2009). 


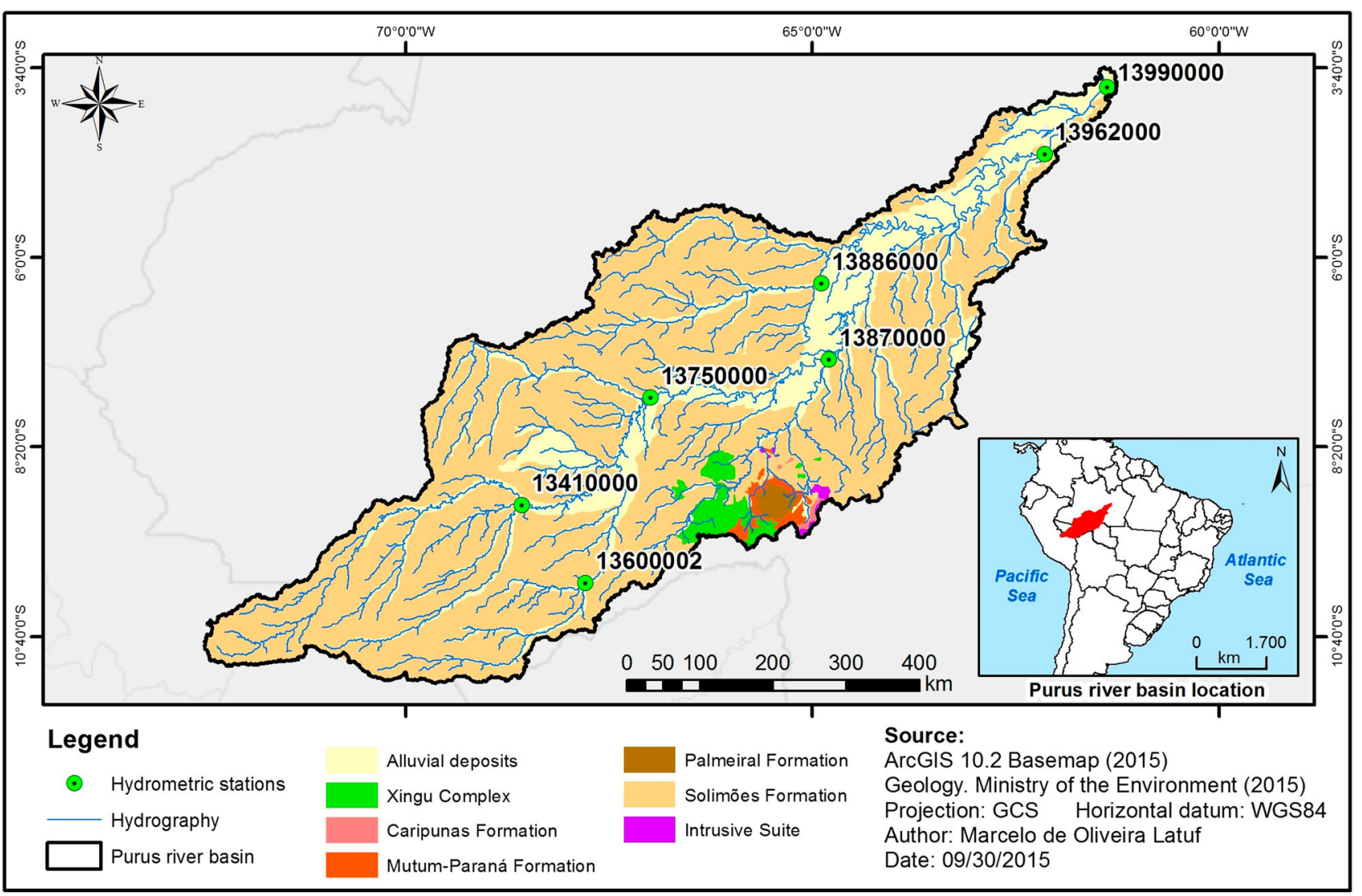

Figure 2. Geology types in the Purus River basin.

The recent history of the Purus River valley occupation process begins in the late nineteenth century and early twentieth century, through the rubber boom. With the decline of the rubber boom in the mid-twentieth century, and through the advance of agricultural frontiers in the Brazilian Amazon region in the early 1970s, there is the introduction of temporary pastures and crops.

Regarding the use and soil cover of the basin, there is a predominance of the Equatorial forest, but there have been significant advances in deforestation because of the urban population growth in major cities of the Brazilian Acre and Amazonas States, as well as the advance of pastures.

\section{River basins hydro-sedimentology}

The erosion is configured as a process of natural evolution of the planet landscape, the main actions being the wear, release, transport and sedimentation of various types of material.

Based on the Systemic Theory of Bertalanffy (1975), many are the elements and components that control erosion, from the water cycle to the soil management and its coverage.

The erosion may be related to several factors, such as winds, water and gravity factors, among others. The erosion based on the water factor, except to the sea erosion, has through rainfall its main detachment mechanism.

Another component that relates to the hydrological cycle, the vegetation cover, for example, has one of its purposes, soil protection against the effects of the direct impact of rain water. The direct impact of raindrops on the soil causes the change in infiltration rate due to the compression of a thin surface layer of the soil, hindering water infiltration process in the soil (Guerra 1999).
As a result of that process, the water could not seep into the ground and it is retained in its microtopography, starting the flooded process. Because of the continuing rainfall, the soil cannot hold water in its microtopography, beginning the runoff (Guerra 1999).

However, the soil being protected by vegetation cover formed by the canopy structure and undergrowth significantly increases its water infiltration capacity, since the breaking of the kinetic energy of raindrops, because it no longer will impact directly on the ground, and because of the addition and cycling of organic matter.

Tricart (1957), in his theory about the balance morphogenetic, appoints the runoff and infiltration as components parallel and perpendicular, respectively. Relations between the components according to the type of soil and vegetation cover, as well as the spatial and temporal variability of rainfall, give support to his theory, which proposes a model for understanding the evolution of landscapes.

Collaborating with this view and considering the watershed as a natural system organized in several subsystems and components, which has a close relationship of interdependence between them, there was, as time passed by, an evolution of techniques and methodological procedures for understanding the hydric and erosive dynamics.

The analysis of the hydrological behaviour, based on sediment dynamics of river channels, it is of significant importance for the planning and management of water resources, especially for the determination of solid discharge, in order to control processes such as erosion, loss of soil fertility, silting of canals and water treatment for supply, among others.

However, the daily monitoring of sediment practice, obtained by the concentration of sediments or in the estimation of sediment discharge in river channels, appears as 
techniques that require exhaustive fieldwork, trained technical staff and time. One of the most used parameters in the indirect estimation of suspended sediment concentration is the turbidity (Walling 1977, Silva et al. 2010, Santos et al. 2012.).

Carvalho et al. (2000) and Merten and Poleto (2006) present sample techniques to collect water plus sediment, and laboratory procedures to determine the suspended sediment concentration $\left(\mathrm{mg} \mathrm{L}^{-1}\right)$. Once the suspended sediment concentration is obtained and associated with the flow of the field measurement time $\left(\mathrm{m}^{3} \mathrm{~s}^{-1}\right)$, it is possible to get the suspended solid discharge, expressed in tons per day $\left(\mathrm{t} \mathrm{day}^{-1}\right)$, according to Carvalho (1994).

The suspended solid discharge is configured as an indicator of the amount of sediment being carried by the river and, indirectly, reflects the environmental quality of the river basin, based on the relationships between use and ground cover, infiltration and runoff.

That indicator even shows us as a comparative of suspended sediment production between river basins, and it is obtained with a relative ease. However, that indicator proves to be challenging when we take into account the diversity of channel patterns as well as variations in the width, depth, flow rate and bed types.

However, one should not compare SSDs in basins with different areas of contribution, because if doing so, there is a creation of a methodological problem. So, there is another indicator that is used in the comparison between SSDs in river basins.

That parameter minimizes the effect of the contributed area of the obtaining point of SSD and is acquired by dividing the suspended solid discharge by drainage area, which results in a value named suspended solid-specific discharge (Jiongxin and Yunxia 2005).

Thus, many researchers use the data from hydrometric stations related to the concentration of suspended sediment and liquid discharges to obtain the suspended solid discharge, and also use the relationship between liquid discharge and suspended solid discharge to the adjustment of suspended solid discharge rating curves (Crawford 1991, Horowitz, 2003, Jiongxin and Yunxia 2005).

Walling (1977) points out the need to verify rating curves accuracy, since in a study conducted by the researcher in England rivers, there were errors of, approximately, $50 \%$ or more to the sediment estimates.

Jansson (1996) adjusted the sediment rating curve of the Reventazón River located in Costa Rica, by separating liquid discharge classes achieving good results.

Therefore, an estimation of a suspended solid discharge depends on the quality of the data obtained in the field, either by sample collection and measurement of direct liquid discharge or by using flow rating curves associated with suspended sediment. Thus, efforts towards the expansion and maintenance of hydrometric networks are required in order to study watershed as well as to verify measurement methods and to check the accuracy of adjustments.

\section{Materials and methods}

Materials and methods were divided into four steps which are: (a) preparation of a digital cartographic base of the Purus River basin, (b) hydrosedimentological data collection and treatment, (c) processing of the average rainfall data and (d) deforestation analysis.

Note that the base period chosen for this work (20002014) sought to select the available data of suspended sediment, flow rates, average rainfall and deforestation for each hydrometric station located in the Purus River basin.

\subsection{Cartographic base preparation}

The procedures adopted for the development of the digital cartographic base consisted of two phases: (a) data acquisition via filers and (b) treatment and spatial adjustments.

The step of acquiring satellite data was obtained by the access to Brazilian and international public institutions servers. Data were obtained from administrative boundaries of Brazilian and South American countries as well as the geology map at a scale of 1:2,500,000, in the Ministry of Environment website http://mapas.mma.gov.br/i3geo/datadownload.htm, in geographic projection without datum. After acquired, all space files have been redesigned for the Geographic projection, adopting the Brazilian official Datum, SIRGAS2000.

On the National Water Agency (ANA) website, http:// www2.snirh.gov.br/home/, spatial information was obtained about the Brazilian Hydrometeorological Network stations belonging to the basin as well as their identification codes. As the file given by ANA is read-only via WebService, it was necessary the making of a space vector format file containing such information, using Geographic and Datum SIRGAS2000 projection spatial references.

For the delimitation of the Purus River basin, its hydrometric station and sub-basins and to obtain the main drainage channels, the digital model arising from the Shuttle Radar Topography Mission (SRTM) was used, with a spatial resolution of $90 \mathrm{~m}$ in its version 4, available in the North American Space Agency (NASA) via http://srtm.csi.cgiar.org/ website. Downloads were made of the following Tiles X/Y: 22_14, 22_15, 23_14, 23_15 and 24_14.

Marques and Silva (2007) methodology was adopted for SRTM images treatment related to the Purus River basin, hydrometric station sub-basins and main drainage channels. To do this, it was used the ArcHydro ${ }^{\circledR}$ Tools extension 10.2, coupled with geographic information system ArcGIS ${ }^{\circledast}$ 10.2, available in GIS Laboratory of the Federal University of Alfenas.

However, to estimate the area of the hydrometric station, the Purus River basin and sub-basin, it was required to redesign the digital elevation model for the Albers projection, adopting the Datum WGS84, due to the significant longitudinal extension of the basin, which prevented the use of a metric projection, such as the Universal Transverse Mercator. It is noteworthy that, according to the Brazilian Institute of Geography and Statistics (IBGE), the Data SIRGAS2000 and WGS84 are compatible and can be used analogously (Ibge 2015).

\subsection{Hydro-sedimentology data collection}

The hydro-sedimentology data related to the Purus River basin were obtained through the stations available via HIDROWEB system, www.hidroweb.ana.gov.br, from the National Water Agency, as seen in Table 1 and Figure 3.

Altogether were found seven stations in the Purus River basin, but in two of them, the Bacaba stations (13886000) 
Table 1. Hydrosedimentometric station in the Purus River basin.

\begin{tabular}{|c|c|c|c|c|c|c|}
\hline Code & Name & Latitude & Longitude & Drainage area $\left(\mathrm{km}^{2}\right)$ & Operation start (year) & River (name) \\
\hline 13600002 & Rio Branco & -9.9750 & -67.8008 & 23,500 & 1984 & Acre \\
\hline 13410000 & Seringal da Caridade & -9.0439 & -68.5772 & 63,100 & 1992 & Purus \\
\hline 13750000 & Seringal Fortaleza & -7.7156 & -66.9997 & 154,000 & 1992 & Purus \\
\hline 13870000 & Lábrea & -7.2581 & -64.7975 & 226,000 & 1992 & Purus \\
\hline $13886000^{\mathrm{a}}$ & Bacaba & -6.3192 & -64.8861 & 37,800 & 1992 & Tapauá \\
\hline $13962000^{\mathrm{a}}$ & Arumã - Jusante & -4.7286 & -62.1453 & 366,000 & 1983 & Purus \\
\hline $13990000^{\mathrm{a}}$ & Beruri & -3.8781 & -61.3575 & 378,000 & 2014 & Purus \\
\hline
\end{tabular}

Source: Brazilian National Water Agency (2015). Source: www.hidroweb.ana.gov.br.

${ }^{a}$ Sedimentological and/or hydrological data very recent or inaccessible by HidroWeb System during the development period of this article.

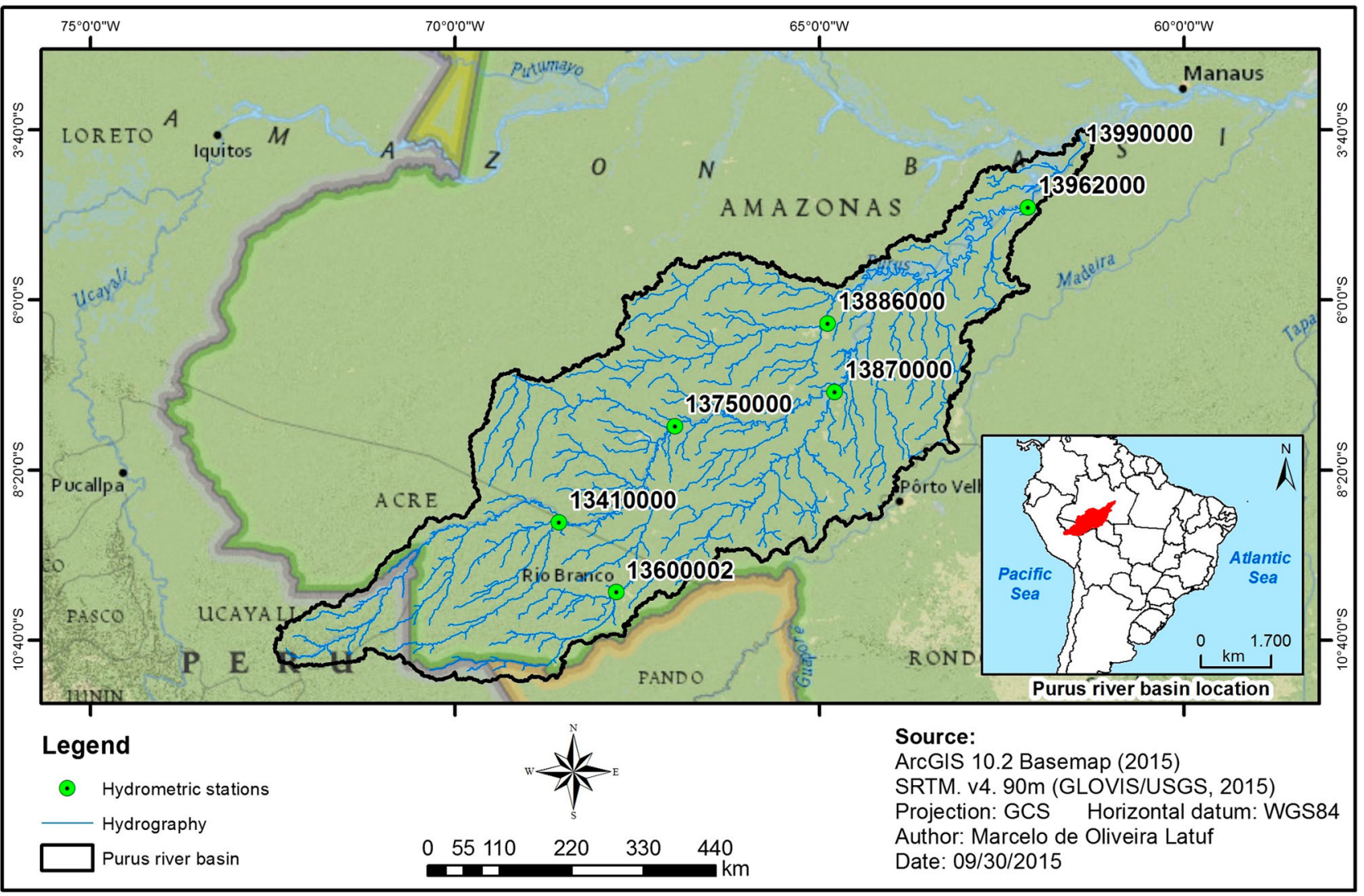

Figure 3. Hydrosedimentometric stations in the Purus River basin.

and Arumã-Jusante (13962000), difficulties were encountered regarding access to data flows via the HIDROWEB system. In the Beruri (13990000) station, very recent suspended solid concentration monitoring data were found, which prevented the development of the suspended sedimentary dynamic evaluation and the setting of the sediment rating curve. So, it was opted not to analyse those stations in this article.

SisCAH 1.0 software (Computational System for Hydrological Analysis), http://www.gprh.ufv.br/?area=softwares, was used to obtain the daily flow of the stations listed in Table 1.

It was acquired the daily data flow which received the same treatments in their time series, in accordance with the method proposed by Tucci (2009), regarding the failure analysis and consistency. It was adopted for this stage some criteria which are: (a) verification of the existence and fault extension, assuming monthly series with a maximum of $5 \%$ failure rate, according to Tucci (2009) and (b) verification of stationary signals in order to identify possible trends changes.

A stationary analysis of stream flow series was performed to verify if they had or not significant changes. This test is performed on the same SisCAH 1.0 and the statistical analysis of the mean and variance using the $t$-test (for medium) and the $F$ test (for variances). In this work, it was adopted the threshold of $95 \%$ probability to check trends.

When it comes to the suspended sediment dynamic assessment in the Purus River basin, it was necessary to estimate the suspended solid discharge curve in each hydrometric station (Table 1).

That estimate included flow data $\left(Q, \mathrm{~m}^{3} \mathrm{~s}^{-1}\right)$ and suspended sediment concentration (SSC, $\mathrm{mg} \mathrm{L}^{-1}$ ) which were obtained via HidroWeb System (http://hidroweb.ana. gov.br/), administered by the Brazilian National Water Agency (ANA) and analysed, later, in spreadsheet.

The statistical adjustment of the suspended solid discharge curve consisted, first, in obtaining the suspended solid discharge (Ssd) for the field measurements managed by the National Water Agency, as Eq. 1, proposed by Carvalho et al. (2000):

$$
\text { Ssd }=(F \times \text { SSC }) \times 0.0864
$$

where Ssd $=$ suspended solid discharge $\left(\mathrm{t} \mathrm{day}^{-1}\right) ; F=$ flow $\left(\mathrm{m}^{3} \mathrm{~s}^{-1}\right)$; SSC $=$ suspended solid concentration $\left(\mathrm{mg} \mathrm{L}^{-1}\right)$.

After obtaining the Ssd, the models regression adjustments were initiated, using the $F$ and SSC variables, with the 
threshold acceptance of the coefficient of determination $\left(R^{2}\right)$ less than 0.70 and confidence interval at $95 \%$ probability.

For error estimation, the statistical root mean squared error (RMSE) was used, as presented by Eq. 2 :

$$
\mathrm{RMSE}=\sqrt{\frac{\sum(\mathrm{Estv}-\mathrm{Obsv})^{2}}{n}}
$$

where $\mathrm{RMSE}=$ root mean squared error $\left(\mathrm{t}\right.$ day $\left.{ }^{-1}\right)$; Estv $=$ estimated value $\left(\mathrm{t} \mathrm{day}^{-1}\right)$, Obsv $=$ observed value $\left(\mathrm{t} \mathrm{day}^{-1}\right)$ and $n=$ number of samples.

Once the suspended solid discharge curves were estimated for all stations, the next phase was to estimate the monthly sediment dynamics, through the application of the adjustment equation to the daily flows data. The results were accumulated per month, in order to verify the monthly suspended solid discharge in each hydrometric station.

It was obtained by Eq. 3, the flow coefficient (Rodriguez 2004), which relates dimensionless, the relation between the precipitate volume of the basin and volume disposed in cross-section:

$$
F=\frac{V d}{V p}
$$

where $F$ : flow coefficient (dimensionless); $V d$ : the total volume drained in the section during the year $\left(\mathrm{m}^{3}\right)$ and $V p$ : the total volume precipitated in the basin which contributes to the section $\left(\mathrm{m}^{3}\right)$.

As for the estimation of the specific SSD, it was applied Eq. 4. Daily data can be accumulated to obtain the monthly and annual estimates (Jiongxin and Yunxia 2005):

$$
\mathrm{SSSD}=\frac{\mathrm{Ssd}}{\mathrm{Da}}
$$

where SSSD: specific suspended sediment discharge $\left(\mathrm{t} \mathrm{km}{ }^{2}\right.$ $\left.\mathrm{day}^{-1}\right)$; Ssd: suspended solid discharge $\left(\mathrm{t} \mathrm{day}^{-1}\right)$ and Da: drained area $\left(\mathrm{km}^{2}\right)$.

\subsection{Mean precipitation estimate}

The mean precipitation estimate in the Purus River basin was made as a result of the monthly data processing from the Tropical Rainfall Measuring Mission (TRMM), due to the inability to use the hydrometric station of the Brazilian Hydrometeorological Network, due to the fact that they are, for the most part, located in the Purus River channel, which would prevent the estimate for a significant portion of the watershed.

Data from the 3B43 product, TRMM version 7, were obtained via the NASA web server in http://mirador.gsfc. nasa.gov/ address whose spatial resolution is $0.25^{\circ}$, equivalent to about $30 \mathrm{~km}$. It was acquired monthly rainfall images from 2000 to 2014.

Data were processed via image-processing software Envi 4.8 of the GIS Laboratory of the Federal University of Alfenas. This processing adopted the methodology presented by Silva (2015), available at http://www.lapig.iesa.ufg.br/lapig/.

After that step has been completed, it was searched the average rainfall in the watersheds of hydrometric stations, cropping images and obtaining the average through statistical mean, acquired by the Geographic Information System $\operatorname{ArcMap}^{\oplus} 10.2$, and, soon after, processed in an electronic spreadsheet.

\subsection{Basin deforestation analysis}

The basin deforestation analysis in the Purus River basin, and especially in sub-basins of the hydrometric stations, was obtained through the series data prepared by the National Institute for Space Research (INPE), via the Amazon Deforestation Calculation Program (PRODES) available in http:// www.obt.inpe.br/prodes/. On the same website, it can be found the material for the methodology consultation to monitor.

Data obtained by PRODES were related to the Digital PRODES program, available in vector format from 2000 to 2014. After from that acquisition, the data series were treated by SIG techniques, with the clipping of the vectors for subbasins stations of interest and further processing in a spreadsheet to account the deforestation dynamics.

\section{Results and discussion}

Due to the inability to access the hydrological data of Bacaba (13886000), Arumã-Jusante (13962000) and Beruri (13990000) stations, because of problems in accessing data via web service and by recent historical data series, it was decided the exclusion of those stations in the analysis of this study.

\subsection{Deforestation analysis}

Brazilian Amazon deforestation began with greater expressiveness in the 1970s, with the advance of the agricultural frontier and introduction of temporary pastures and crops. With this soil use, part of the Amazon region, under Brazilian domain (Amazon), suffered an abrupt change in regard to economic and land configuration (Becker 1997).

The Amazon model of human occupation was a transplanted model adopted based on the model occupation from other Brazilian regions; however, many are the characteristics that differ from the Amazon biome to other Brazilian natural regions, such as the mean temperature, annual rainfall and relative humidity, among others.

With eyes turned to the Amazon, cities had a rate of significant population growth in recent decades such as the cities of Manaus/AM, Belém/PA, Porto Velho/RO and Rio Branco/ AC, among others. This population growth pointed by the Brazilian demographic census, conducted by the Brazilian Institute of Geography and Statistics, helps us to understand the deforestation dynamics in the Amazon, in order to help meet the population's demand for food crops.

From that historic moment and because of a low efficiency in mapping and land registration by the Brazilian government at that time, it began a quest for occupation, registration and lands dismemberment, many of them belonging to the Union, via grabbing actions. The land-grabbing process was the main drive shaft of the land demarcation in the Brazilian Amazon Land Grabbing, and it was the method of taking possession without a legal requirement for land demarcation purposes; in other words, no one knows who owns the land. Thus, someone takes possession of that piece of ground and from then, that person is considered to be the owner of the land.

So, that process began the deforestation of the land in a significant way, giving way to temporary pastures and crops. Due to the intrinsic soil characteristics in the area, quickly it was necessary to expand the soil-used area for pasturing livestock and to plant. 


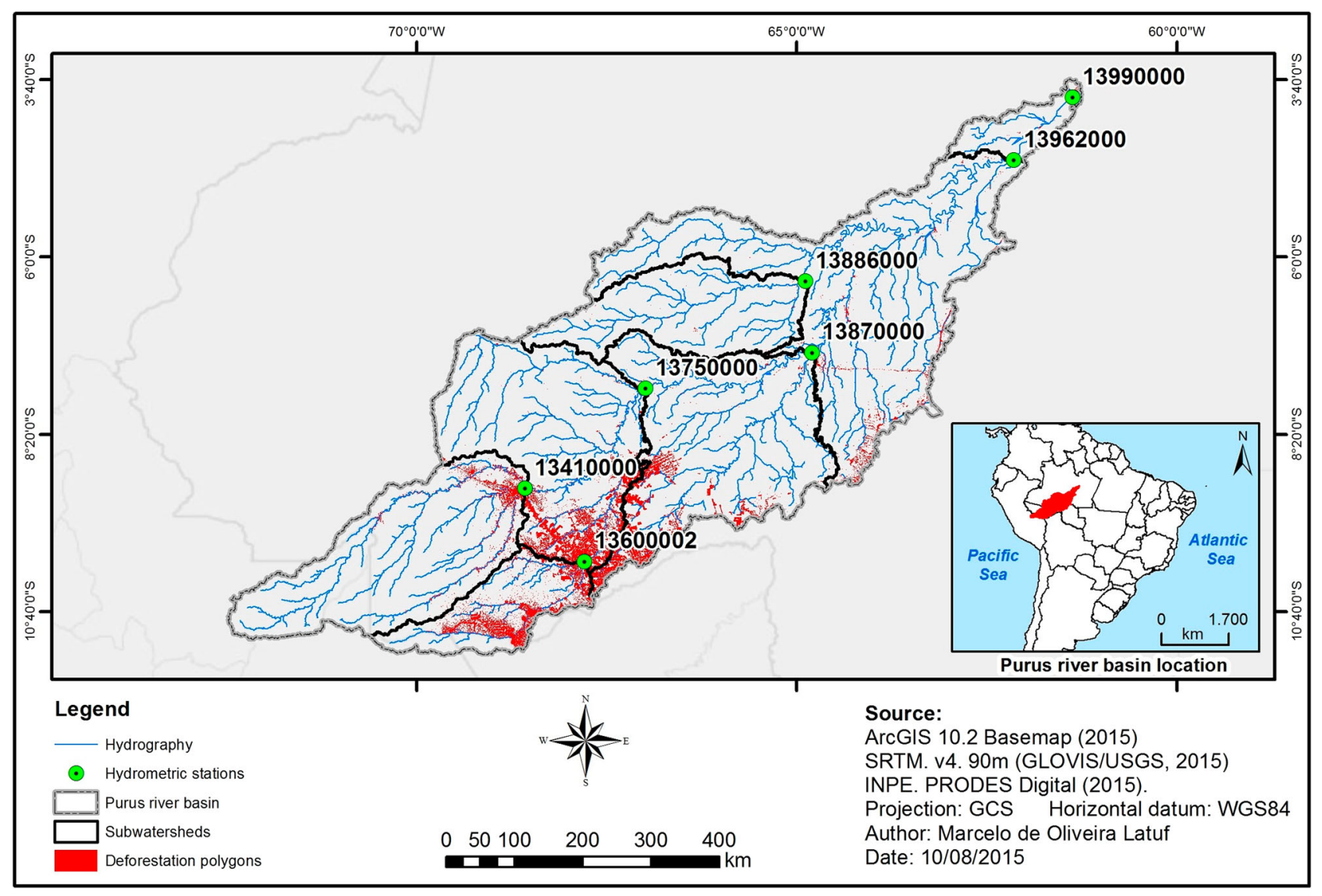

Figure 4. Deforestation polygons in the Purus River basin (from 2000 to 2014).

The deforestation dynamics in the Purus River basin followed the already cited occupation model. Although, efforts regarding the land regularization, as well as the monitoring and illegal deforestation combat, have been made by the Federal Government and by the various states that form the Legal Amazon Brazilian.

The National Space Research Institute, in its Amazon Deforestation Calculation Program (PRODES), annually conducts the monitoring of the deforestation rates and polygons mapping.

In this context, Figure 4 shows the deforestation spot of the Purus River basin from 2000 to 2014.

It is evident that the greater expressiveness of deforestation areas in the Purus River basin are located mainly in the upper reaches and the sub-basin of the Acre River, a tributary of its right bank.

The Acre River basin is part of the Acre southeast region, which has the largest population concentration of Acre, and the highest concentrations of anthropogenic environments. Also, the Acre River flows into the Purus River in the Amazonian town named Boca do Acre (Acre 2006). The largest deforestation occurrences are around the Acre capital called Rio Branco/AC where is located the same name station, with code 13600002 .

It is noteworthy that the deforestation linearity between 13600002 and 13410000 stations is due to the BR-364 road which connects Rio Branco/AC to the city of Acre named Sena Madureira/AC located in the banks of the Purus River. There is a relationship between deforestation vectors associated with roads in the Amazon region.

It should be noted that due to pedogeomorphologically characteristics, building roads in the Amazon region appear as a task of significant complexity, given the peculiarities of the soil and relief. Thus, water splitters are local, often chosen to be a local road. It may be noted that the deforestation spot follows the water splitter between 13750000 and 13870000 stations.

Table 2 shows the deforestation dynamics in the Purus River basin, relying on the drainage areas of hydrometric stations adopted in this study.

The year 2000 sets up the sum of the areas deforested by then, serving as the base year, for monitoring and estimating

Table 2. Deforestation estimate for the sub-basins of hydrosedimentometric stations (from 2000 to 2014).

\begin{tabular}{|c|c|c|c|c|}
\hline \multirow[b]{2}{*}{ Year } & \multicolumn{4}{|c|}{ Deforestation per hydrometric station $\left(\mathrm{km}^{2}\right)$} \\
\hline & $\begin{array}{l}\text { Rio Branco } \\
(13600002)\end{array}$ & $\begin{array}{l}\text { Seringal da } \\
\text { Caridade } \\
(13410000)\end{array}$ & $\begin{array}{c}\text { Seringal } \\
\text { Fortaleza } \\
(13750000)\end{array}$ & $\begin{array}{c}\text { Lábrea } \\
\text { (13870000) }\end{array}$ \\
\hline $2000^{a}$ & 484.0 & 198.1 & 1229.3 & 1724.4 \\
\hline 2001 & 181.2 & 51.5 & 434.6 & 709.5 \\
\hline 2002 & 162.8 & 84.7 & 528.6 & 889.2 \\
\hline 2003 & 217.3 & 212.4 & 893.3 & 1359.5 \\
\hline 2004 & 193.0 & 66.0 & 575.1 & 974.2 \\
\hline 2005 & 158.2 & 100.2 & 453.6 & 747.4 \\
\hline 2006 & 39.0 & 30.5 & 213.3 & 464.6 \\
\hline 2007 & 18.2 & 27.4 & 116.7 & 234.6 \\
\hline 2008 & 57.9 & 37.9 & 178.0 & 257.8 \\
\hline 2009 & 31.4 & 24.3 & 107.7 & 164.8 \\
\hline 2010 & 32.3 & 53.3 & 166.5 & 213.4 \\
\hline 2011 & 64.3 & 49.7 & 222.3 & 307.6 \\
\hline 2012 & 59.5 & 55.0 & 208.1 & 298.8 \\
\hline 2013 & 47.9 & 48.1 & 154.9 & 286.3 \\
\hline 2014 & 87.0 & 71.6 & 268.3 & 409.0 \\
\hline Total & 1834.1 & 1110.8 & 5750.2 & 9041.1 \\
\hline $\begin{array}{l}\text { Sub-basin } \\
\quad \text { deforestation (\%) }\end{array}$ & 8 & 2 & 4 & 4 \\
\hline Average & 122.3 & 74.1 & 383.3 & 602.7 \\
\hline
\end{tabular}

Source: Prodes Digital (2015).

${ }^{\mathrm{a}}$ Deforestation until 2000. 

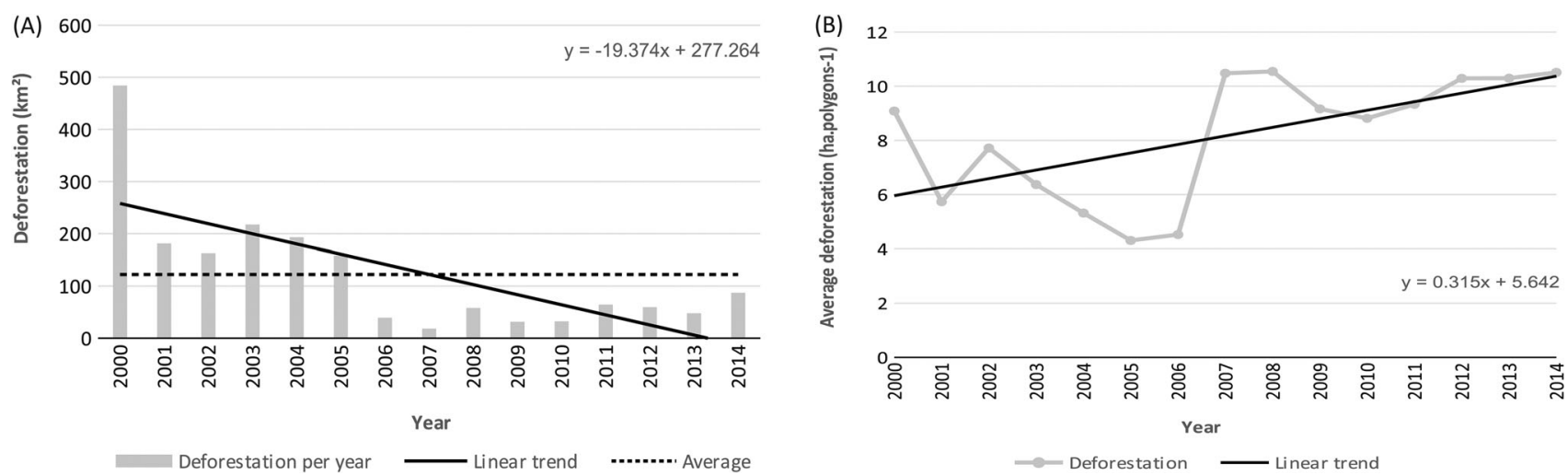

Figure 5. Deforestation in Rio Branco station (13600002) from 2000 to 2014.

Source: (a) Annual deforestation; (b) average deforested area according to the number of mapped polygons.

the following years. It is observed that the drainage area of Rio Branco station, compared to the Seringal da Caridade station, has a total of more deforestation by $65 \%$, reaching an annual average of $122.3 \mathrm{~km}^{2}$ year ${ }^{-1}$ (2000-2014).

These data reveal, when linked to population data, the influence of Acre deforestation in southeast areas of that sub-basin. However, the contribution area for the Seringal da Caridade station does not have a significant urban concentration, being the main one around the town of Sena Madureira/AC.

It can be seen in Figure 5, the occurrence of annual deforestation in Rio Branco Station contribution area (13600002) (Figure 5(a)), as well as in Figure 5(b), the average deforested area according to the number of mapped polygons.

There is a clear reduction of the deforested basin area from 2000 to $2014\left(-19.4 \mathrm{~km}^{2}\right.$ year $\left.^{-1}\right)$, mainly due to the government actions of inspection and control, especially after 2005, when the size of the mapped areas did not exceed the average one in the period, setting up a downward trend.

Although, when Figure 5(b) is analysed, it can be noticed that the average deforested area for polygons has a growth trend of about 0.3 ha year $^{-1}$ from 2000 to 2014 .

This induces the idea that the total deforestation area is actually reducing whereas the areas on average per polygon are being increased, in other words, when it comes to deforestation practice the areas are proportionately larger.

This behaviour is repeated in all of the other hydrometric station contributed area considered in this study, as evidenced in Table 3.

The deforestation increase trend followed by polygons, as well as the continued advancement of deforestation spots, can affect the forecast for the year 2030, conducted by Nepstad et al. (2008) for the Amazon biome, as shown in Figure 6.

In this scenario, there is a clear advance of deforestation areas, based on the data collection until 2008. There are increasing deforestation areas in the region covered by the Acre southeast to the Amazonian town of Boca do Acre. Another point that stands out is the growth deforestation in the part of the BR-364 road which connects Rio Branco/AC

Table 3. Deforestation trends to the other stations (2000-2014).

\begin{tabular}{lcc}
\hline & \multicolumn{2}{c}{ Deforestation trend $^{\mathrm{a}}$} \\
\cline { 2 - 3 } Hydrometric station & $\mathrm{km}^{2}$ year $^{-1}$ & ha polygon $^{-1}$ \\
\hline Seringal da Caridade & -6.74 & +0.34 \\
Seringal Fortaleza & -52.30 & +0.33 \\
Lábrea & -80.57 & +0.35
\end{tabular}

${ }^{\mathrm{a}}$ Linear regression equation $\beta$ based on the years. to Sena Madureira/AC. This was done by the expected completion of its paving.

Undoubtedly, the areas with the highest growth, predicted by Nepstad et al. (2008), lie on the axis of BR-319, which connects Porto Velho/RO to Manaus/AM. Those are considered two important Brazilian state capitals, the first being the subject of significant speculation and economic growth due to construction of hydropower plants.

\subsection{Average precipitation analysis}

The Brazilian Amazon has significant monthly and annual average rainfalls. According to Fisch et al. (2015), the average rainfall of the Amazon region is about $2300 \mathrm{~mm} \mathrm{year}^{-1}$, but there are places (in the triple border between Brazil, Colombia and Venezuela) where the yearly total is close to $3500 \mathrm{~mm}$. There are also regions in Acre, southwest of the Amazonas State and near the border with Peru and Bolivia where the total yearly reaches approximately $2000 \mathrm{~mm}_{\text {year }}{ }^{-1}$.

The Amazon region is the place where the Continental Equatorial Mass (Ecm) is originated. One of its main characteristics is being a warm and moist air mass (Machado and Torres 2011). Its positional dynamics is influenced by the solar zenith between the Tropics of Capricorn and Cancer, known as Ecuador Dynamic or Thermal Ecuador.

In this region of the planet known as the Intertropical Zone (between the tropics), there are significant convective activity associated with the upward flow of warm moist air. Also there is the arrival of the trade winds and instability lines originated in the north-northeast Atlantic coast, forming a singular type of cloud featured in this region, the cumulonimbus. This kind of cloud is responsible for high-intensity rainfall $\left(\mathrm{mm} \mathrm{h}^{-1}\right)$ and significant amounts of rain $(\mathrm{mm})$.

In the Purus River basin, Ecm is the main active air mass in practically all year round, but there are incursions of the Atlantic Polar Mass (Pam; cold and wet) and Continental Tropical Mass (Tcm; hot and dry). The Ecm is related to the phenomenon which chills some regions, particularly common in the south of the Amazon, in the Rondonia and Acre States, mainly associated with the austral winter. When it comes to the Tmc, it advances in the Amazon region influencing the Purus River weather basin, when there is the boreal summer, in other words, when the greatest intensity of $\mathrm{Ecm}$ actions is located in the northern hemisphere due to the Ecuador Dynamic.

This contributes to a peculiar dynamic distribution of rainfall throughout the year in the river basin, with regions 


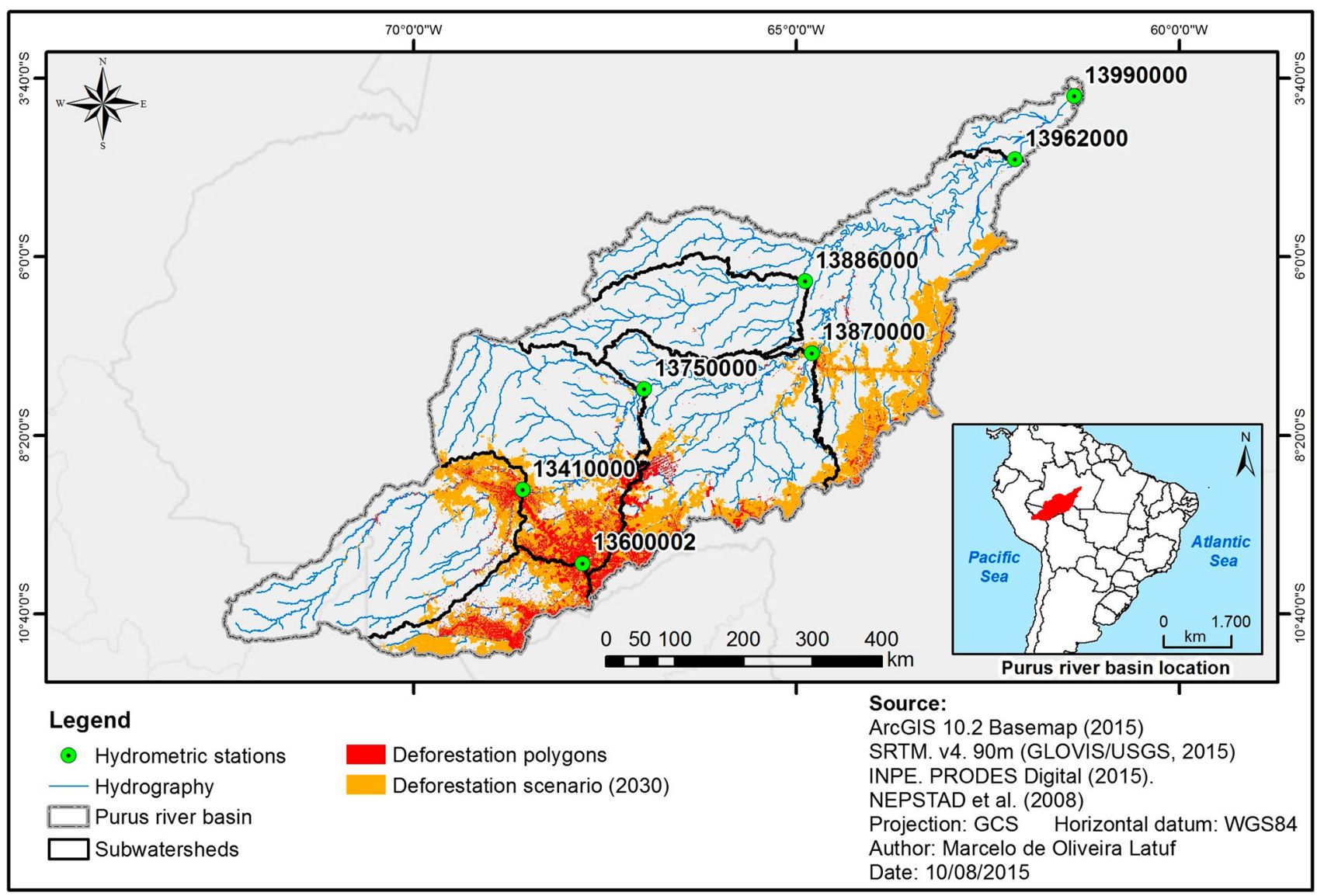

Figure 6. Deforestation scenario for the Purus River basin (2030).

with more intensive rainfall than others, depending on the dynamics of the air masses above (Ecm and Tcm, mainly). In Figure 7, there is the exposure of the mean rainfall in the Purus River basin, obtained by the TRMM sensor from 2000 to 2014.
Note that there are two well-defined seasons in the Purus basin, a rainfall about $268.5 \mathrm{~mm} \mathrm{month}^{-1}$, from October to April and another dry season, with a monthly average of $88.6 \mathrm{~mm}$, covering the months of MaySeptember.

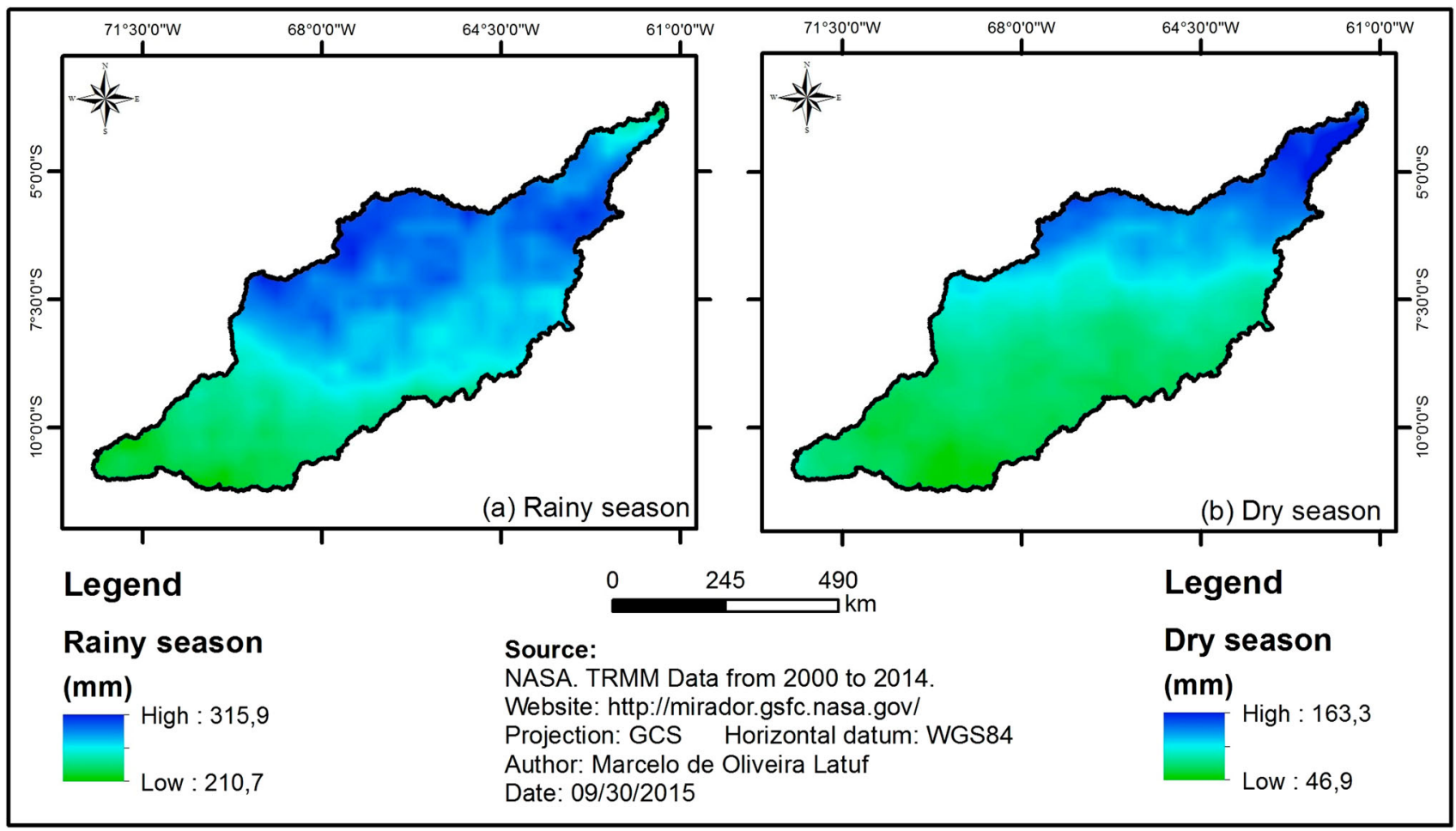

Figure 7. Precipitation dynamics for the Purus River basin (2000-2014). 

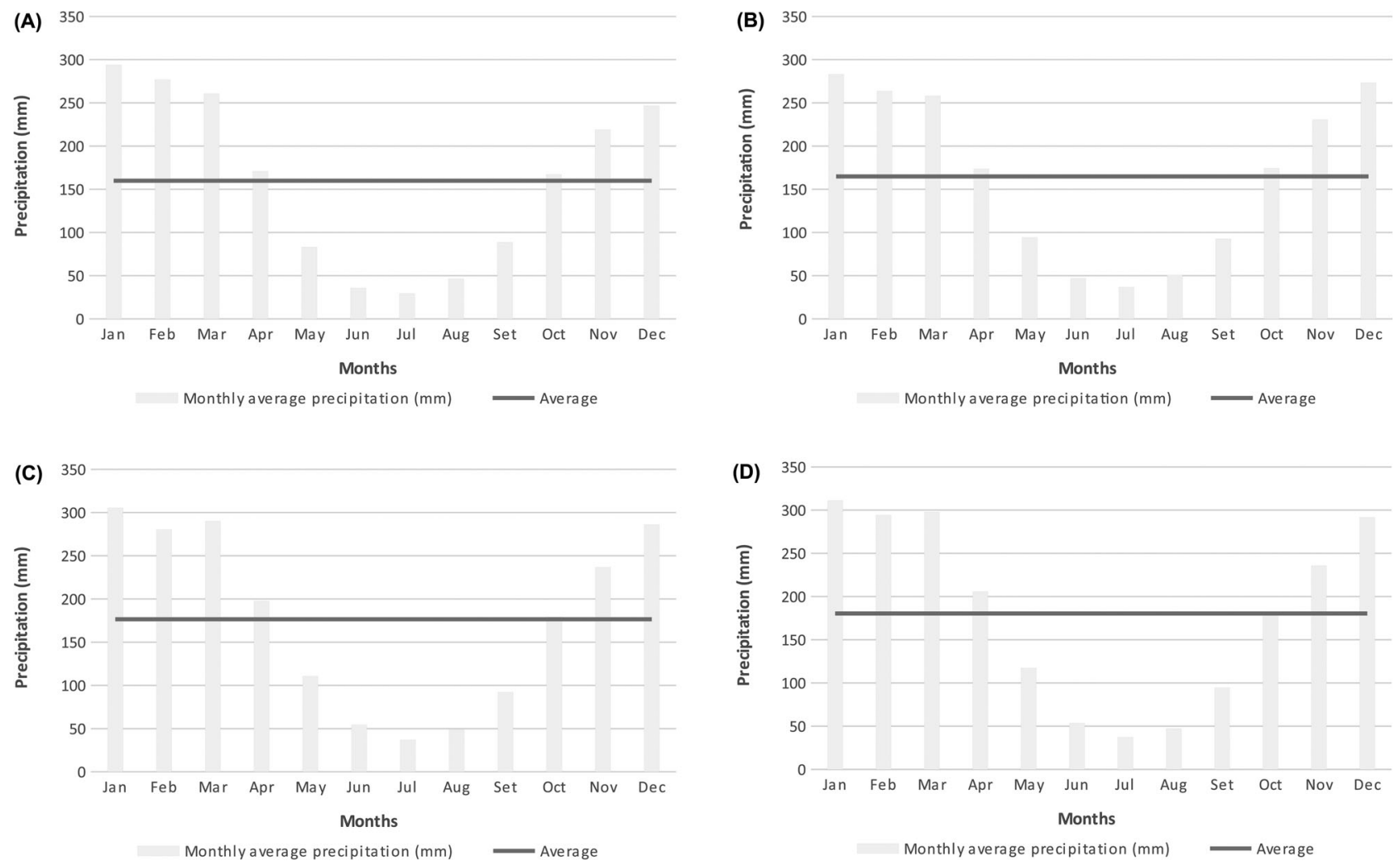

Figure 8. Monthly average precipitation of the sub-basins of hydrosedimentometric stations (from 2000 to 2014). Source: (a) Rio Branco; (b) Seringal da Caridade; (c) Seringal Fortaleza and (d) Lábrea.

Analysing monthly dynamics of the contribution areas of hydrometric stations (Figure 8), it can be noted that there is a seasonal pattern of rainfall for all analysed sub-basins, Climate Tropical typical, which has two well-defined seasons by definition, in this case, a rainy and a dry season.

The rainy season can be defined as the months in which the average rainfall exceeds the monthly average, on the other hand, the dry season is defined by the months in which the average rainfall does not exceed the monthly average. Performing an analysis of the sub-basins average, there is a mean rainfall in the headwater regions which is below the average of the middle river channel, as shown: Branco River station $159.9 \mathrm{~mm} \mathrm{month}^{-1}$ (Figure 8(a)), Seringal da Caridade station $164.8 \mathrm{~mm} \mathrm{month}^{-1}$ (Figure 8(b)), Fortaleza station $176.5 \mathrm{~mm} \mathrm{month}^{-1}$ (Figure $8(\mathrm{c})$ ) and Lábrea station $180.4 \mathrm{~mm} \mathrm{month}^{-1}$ (Figure $8(\mathrm{~d})$ ).

Additionally, the annual average precipitation of the subbasins, already mentioned, from 2000 to 2014, is: $1918.7 \mathrm{~mm}$ year $^{-1}$ (Rio Branco station), $1978.1 \mathrm{~mm}_{\text {year }}{ }^{-1}$ (Seringal da Caridade station), $2118.3 \mathrm{~mm}$ year $^{-1}$ (Seringal Fortaleza station) and $2164.3 \mathrm{~mm}$ year $^{-1}$ (Lábrea station).

On the other hand, taking as an analysis the dynamic annual rainfall from 2000 to 2014 ( 15 years), it can be noticed that for all analysed sub-basins, there is an increasing trend of total annual rainfall, as seen in Figure 9.

It is presented, in Table 4, a table summary of the statistics obtained for the rainfall in the sub-basins of hydrometric stations located in the Purus River basin.

\subsection{Suspended solid discharge}

The suspended solid discharge evaluation presented by the hydrometric stations located in the basin of the Purus River (Table 1), except for the 13886000, 13962000 and
13990000 stations, had as steps (a) the suspended solid discharge rating curve adjustment, (b) an estimate of the suspended solid discharge as well as the search for a trend and (c) the suspended solid discharge and statistical adjustment proposition.

\subsubsection{Suspended solid discharge rating curve}

The rating curve is an indirect procedure for estimating values of certain parameters, using other indicators that are easier to access and obtain. This method was adopted to estimate the suspended solid discharge $\left(t \mathrm{day}^{-1}\right)$ for each observation in the hydrological database of the National Water Agency and available at HidroWeb System.

Table 5 shows the settings of the suspended solid discharge rating curve $\left(\mathrm{t} \mathrm{day}^{-1}\right)$, obtained for the hydrometric stations in the Purus River basin.

Equations with the best adjustment degree have been chosen using the coefficient of determination $\left(R^{2}\right)$. If the $R^{2}$ in the equations was too close, the decision to switch would be the root mean squared error (RMSE). However, it was decided in this study to use the $R^{2}$ obtained in the adjustment, because there is no significant proximity between the values when they are analysed for each station separately. In Figure 10, the obtained adjustments chosen by station can be observed graphically.

\subsubsection{Suspended solid discharge estimate}

To implement this step, it was obtained the daily flows data of hydrometric stations, via web access, found in the hydrological database of the National Water Agency and available at HidroWeb System.

Unfortunately, the data available for the stations do not include the same base period used in the analysis of 

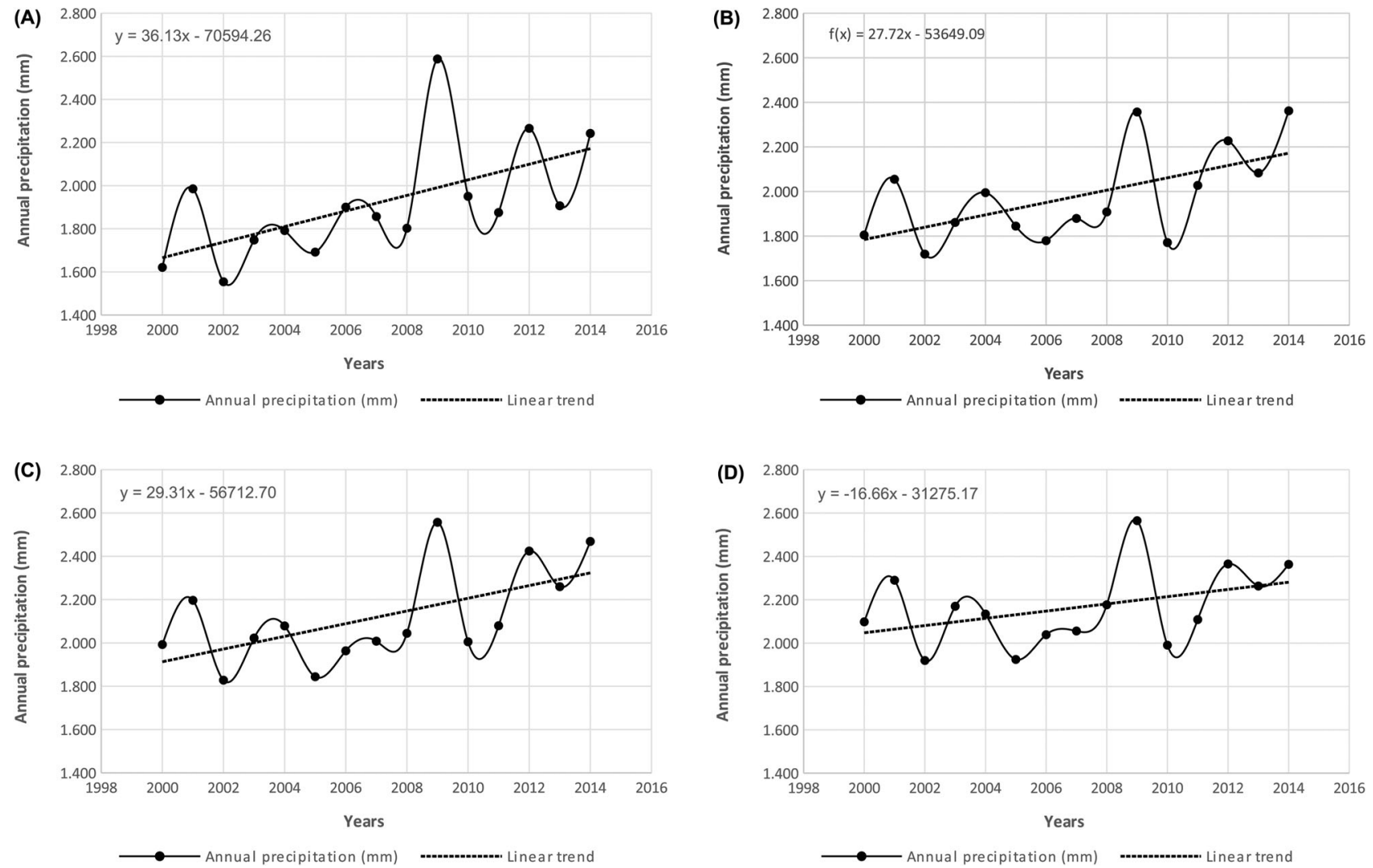

Figure 9. Annual average precipitation of the sub-basins of hydrosedimentometric stations (from 2000 to 2014).

Source: (a) Rio Branco; (b) Seringal da Caridade; (c) Seringal Fortaleza and (d) Lábrea.

Table 4. Summary of rainfall statistics of the hydrosedimentometric stations sub-basins (from 2000 to 2014).

\begin{tabular}{|c|c|c|c|c|c|}
\hline \multirow[b]{2}{*}{ Station } & \multicolumn{2}{|c|}{ Average precipitation } & \multirow{2}{*}{ Rainy season } & \multirow{2}{*}{ Dry season } & \multirow{2}{*}{$\begin{array}{c}\text { Precipitation trend } \\
\text { mm year }^{-1}\end{array}$} \\
\hline & $\mathrm{mm}_{\text {year }}{ }^{-1}$ & $\mathrm{~mm} \mathrm{month}{ }^{-1}$ & & & \\
\hline Rio Branco & 1918.1 & 159.9 & 233.6 & 56.7 & +36.1 \\
\hline Seringal da Caridade & 1978.1 & 164.8 & 236.7 & 64.3 & +27.7 \\
\hline Seringal Fortaleza & 2118.3 & 176.5 & 253.7 & 68.5 & +29.3 \\
\hline Lábrea & 2164.8 & 180.4 & 259.3 & 70.0 & +16.7 \\
\hline
\end{tabular}

${ }^{a}$ Linear regression equation $\beta$ based on the years.

Table 5. Summary of adjustments made for suspended solid discharge rating curves.

\begin{tabular}{|c|c|c|c|c|}
\hline Hydrosedimentometric station & Method & $R^{2}$ & Equation $^{\mathrm{a}}$ & RMSE (t day ${ }^{-1}$ ) \\
\hline \multirow[t]{5}{*}{ Rio Branco $(n=93)$} & Exponential & 0.6977 & $876.05 \mathrm{e}^{0.0037 x}$ & 475,992 \\
\hline & Linear & 0.7879 & $47.197 x-4646.7$ & 10,387 \\
\hline & Logarithmic & 0.5013 & $13204 \ln (x)-56.379$ & 15,927 \\
\hline & Polynomial & 0.8699 & $0.022 x^{2}+15.201 x+530.5$ & 8136 \\
\hline & Potency & 0.9196 & $1.4073 x^{1.481}$ & 8567 \\
\hline \multirow[t]{5}{*}{ Seringal da Caridade $(n=62)$} & Exponential & 0.7009 & $1831 e^{0.0013 x}$ & $1.9 \times 10^{-5}$ \\
\hline & Linear & 0.7371 & $109.7 x-20.984$ & 116,516 \\
\hline & Logarithmic & 0.5842 & $117067 \ln (x)-603.725$ & 146,524 \\
\hline & Polynomial & 0.7481 & $-0.0083 x^{2}+151.72 x-39069$ & 114,034 \\
\hline & Potency & 0.9146 & $0.1298 x^{1.8075}$ & 144,377 \\
\hline \multirow[t]{5}{*}{ Seringal Fortaleza $(n=71)$} & Exponential & 0.5977 & $5945.4524 e^{0.0005 x}$ & 856,276 \\
\hline & Linear & 0.3922 & $48.9463 x-23606.5$ & 203,610 \\
\hline & Logarithmic & 0.3393 & $133.782 .1 \ln (x)-870231.8$ & 212,280 \\
\hline & Polynomial & 0.4153 & $-0.0034 x^{2}+83.904 x-69.586$ & 199,707 \\
\hline & Potency & 0.8200 & $0.0895 x^{1.6803}$ & 215,682 \\
\hline \multirow[t]{5}{*}{ Lábrea $(n=79)$} & Exponential & 0.7347 & $6559.3 e^{0.0003 x}$ & 111,266 \\
\hline & Linear & 0.6022 & $26.6328 x-30507.6$ & 97,229 \\
\hline & Logarithmic & 0.5344 & $117156.9 \ln (x)-844771.2$ & 105,197 \\
\hline & Polynomial & 0.6023 & $-0.0001 x^{2}+27.29 x-31680.8$ & 97,316 \\
\hline & Potency & 0.8548 & $0.0610 x^{1.6287}$ & 99,924 \\
\hline
\end{tabular}

${ }^{\mathrm{a}} X$ value: daily flow in the monitoring section $\left(\mathrm{m}^{3} \mathrm{~s}^{-1}\right)$.

deforestation and precipitation. The data consisted of daily flows that intersect with the other aforementioned data start in January 2000 going until July 2010. However, this scenario does not compromise the analysis on the whole, but there is a gap to be filled later in other studies.

Depending on the equations obtained by regression analysis, the equations were applied to the daily flow of 

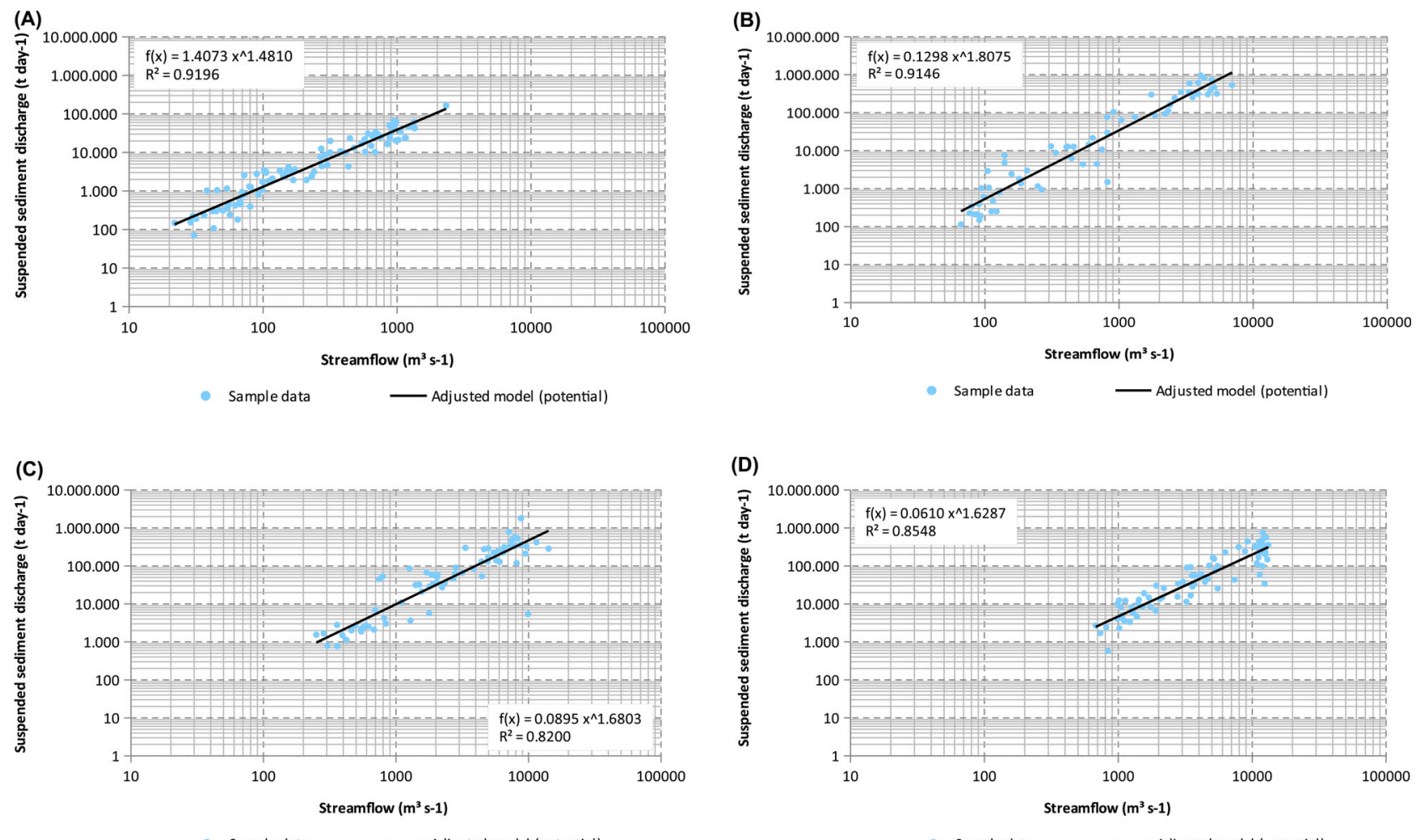

Figure 10. Adjustments chosen to estimate the suspended solid discharge curve. Source: (a) Rio Branco; (b) Seringal da Caridade; (c) Seringal Fortaleza and (d) Lábrea.

hydrometric stations from January 2000 to December 2010, in order to obtain the daily suspended solid discharge. Those data were accumulated per month and they are presented in Figure 11, respectively for the Rio Branco sub-basin (Figure 11(a)), Seringal da Caridade sub-basin
(Figure 11(b)), Seringal Fortaleza sub-basin (Figure 11(c)) and Lábrea sub-basin (Figure 11(d)).

Analysing, visually, the graphs of monthly suspended solid discharge dynamics for some of the hydrometric stations in the Purus River basin, it is observed that the largest increase
(A)

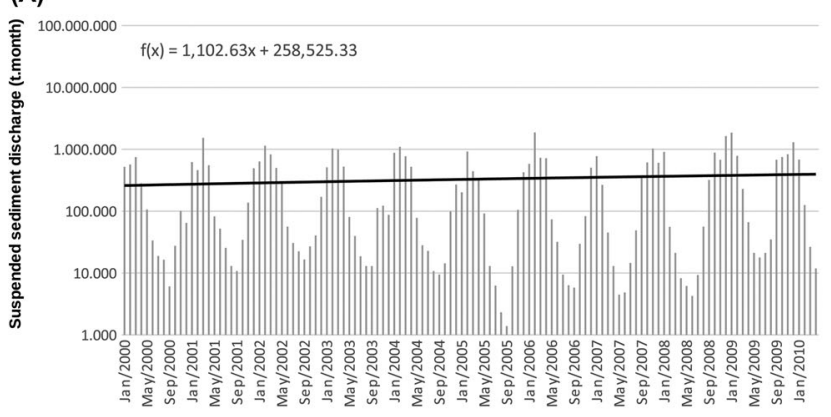

Months

(C)

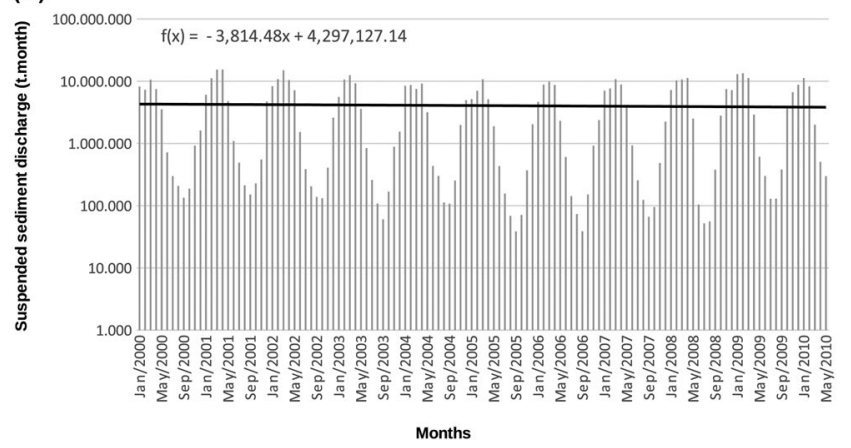

(B)

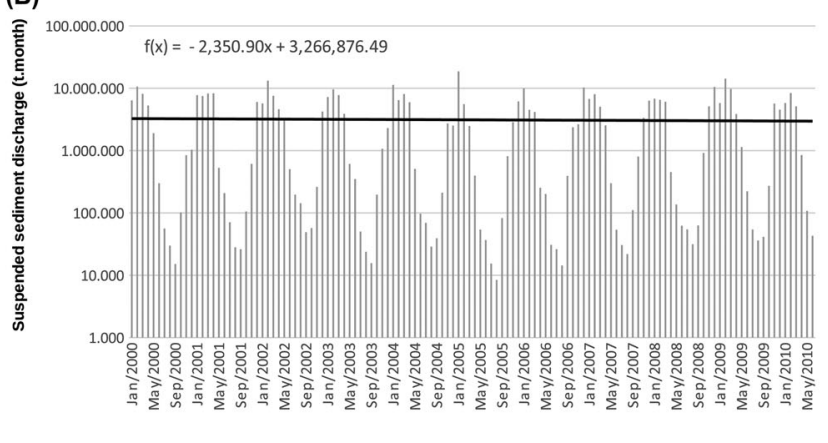

(D)

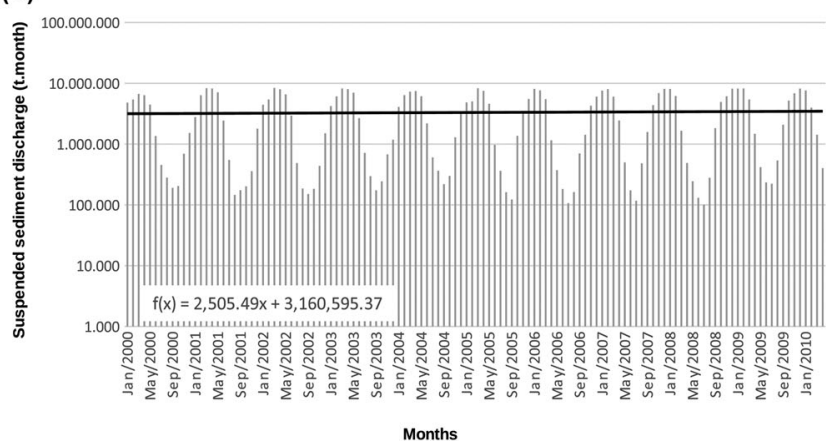

Figure 11. Monthly dynamics of SSD (from 2000 to 2010).

Source: (a) Rio Branco; (b) Seringal da Caridade; (c) Seringal Fortaleza and (d) Lábrea. 
due to the slope of the trend line for the period 2000-2010 is associated with Rio Branco station sub-basin, with an average annual increase of $1103 \mathrm{t}$ month $^{-1}$.

This increase is qualitatively associated with the deforestation dynamic in the sub-basin, which achieved the highest specific average deforestation per unit area for the period analysed ( $8 \%$, see Table 2$)$, that is, $8 \%$ of the basin is under effect of human activities in areas previously converted into other types of land use.

In this analysis can be included the fact that there is a rainfall average increase of $36.1 \mathrm{~mm} \mathrm{year}^{-1}$ in sub-basin which provokes a higher runoff process, when compared to places where the cover of the forest canopy, as well as the understory, protects the soil from the water erosion process.

The Seringal da Caridade and Seringal Fortaleza subbasins obtained a drop in the production of suspended sediments for the period 2000-2010, as most likely seen in a scale effect, as reported by Mediondo and Tucci (1997). The Seringal da Caridade station area contribution is smaller, 59\%, than Seringal Fortaleza and only has $2 \%$ of deforestation $\left(1110.8 \mathrm{~km}^{2}\right)$, and that effect extends to the most downstream station in the Purus River, the Seringal da Fortaleza station.

Even with the increased rainfall average on those two sub-basins, no effects were found in the increased sediment production due to a greater soil protection from the water erosion provoked by rainfall.

However, when it comes to the Lábrea station located downstream from the Seringal Fortaleza station, there is a reverse behaviour. There is an increase of $2506 \mathrm{t} \mathrm{month}^{-1}$ from 2000 to 2010 ( $\beta$ coefficient - Figure 11(b)). Several factors contributed to this phenomenon, since there was an increase in average rainfall in this sub-basin of approximately $17 \%$, but the largest contributor, in a qualitative analysis, was the deforestation increase in the area.

In the hydrometric Seringal Fortaleza station, there is a deforestation area of approximately $5750 \mathrm{~km}^{2}$ from 2000 to 2014; however, for the same period, there was an accumulated deforestation of approximately $9040 \mathrm{~km}^{2}$, in the contributing area of the Lábrea station, that is there was an increase of $57.2 \%$. Thus, there is an association between rainfalls, but mostly between the land use and cover, in controlling suspended sediment dynamics in the Purus River basin.

Using qualitative analysis as a background for the parameter that relates the total volume precipitate in the basin and flow of the outflow section, that parameter already mentioned above is related to the flow coefficient (Eq. 3), in which 1 represents the conversion of all the rain in flow rate and 0 represents that there was no runoff.

Moreover, the monthly average flow rates of the hydrometric stations were obtained and with the rainfall estimate by the TRMM, it was possible to infer the runoff coefficients for the same stations, as shown in Figure 12.

Because of the linear adjustment slope, the sub-basin that presented a more expressive increase when it comes to the runoff coefficient was precisely the Lábrea sub-basin, by embracing all the other stations areas of contribution. However, it should be noted that the increase of this parameter with respect to the Rio Branco sub-basin was superior to the other stations (Seringal da Caridade and Seringal da Fortaleza), most of it associated with the deforestation advance in the basin and the increase of the average rainfall.

Thus, the soil becoming more exposed to the actions of the kinetic energy from rainwater cannot have the same
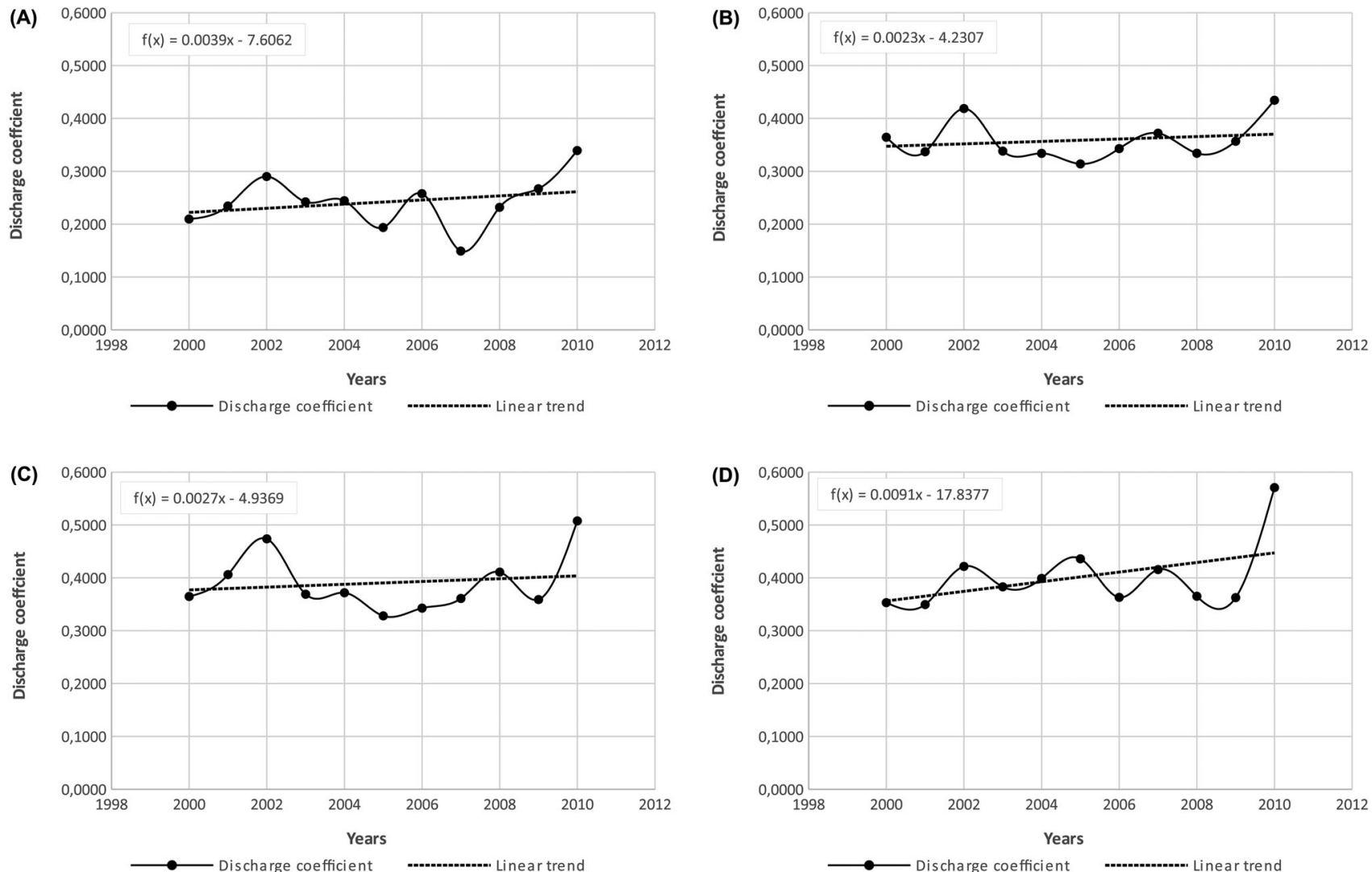

Figure 12. Discharge coefficient dynamic from 2000 to 2010.

Source: (a) Rio Branco; (b) Seringal da Caridade; (c) Seringal Fortaleza and (d) Lábrea. 
Table 6. Suspended-specific sediment production $\left(\mathrm{t} \mathrm{km}^{2}\right.$ month $\left.^{-1}\right)$.

\begin{tabular}{lrccr}
\hline & \multicolumn{4}{c}{ Hydrosedimentometric stations } \\
\cline { 2 - 5 } Months & Rio & Seringal da & Seringal \\
Branco & Caridade & Fortaleza & Lábrea \\
\hline January & 27.0 & 113.4 & 44.2 & 19.0 \\
February & 40.9 & 145.6 & 58.0 & 26.6 \\
March & 40.7 & 125.3 & 75.1 & 35.1 \\
April & 29.3 & 87.4 & 63.3 & 34.2 \\
May & 7.9 & 21.8 & 27.2 & 26.5 \\
June & 2.2 & 4.9 & 6.5 & 9.9 \\
July & 0.9 & 1.3 & 2.1 & 2.6 \\
August & 0.5 & 0.7 & 1.0 & 1.1 \\
September & 0.4 & 0.4 & 0.6 & 0.7 \\
October & 1.3 & 2.2 & 1.0 & 0.9 \\
November & 3.5 & 16.9 & 4.7 & 2.7 \\
December & 14.3 & 58.6 & 18.8 & 7.7 \\
Sum & 169.0 & 578.4 & 302.5 & 167.1 \\
Average per month & 14.1 & 48.2 & 25.2 & 13.9 \\
\hline
\end{tabular}

infiltration rates when compared to soils under forest canopy and understory preserved (Guerra 1999). In this regard, it can be noticed that there is an runoff increase at the expense of infiltration, which can generate maximum peak flows, increasing flood events, being exemplified by recent events in Acre capital, Rio Branco, in 2015 (Acre 2015) when almost 86,000 people were affected by the flooding in the Acre River.

The little increase showed by the Seringal da Caridade and Seringal da Fortaleza stations is due to the fact, as mentioned above, of hydrological scales defended by Mediondo and Tucci (1997).

\subsubsection{Estimated suspended solid-specific discharge}

The estimated suspended solid-specific discharge appears as a widely used parameter for comparisons of sediment yield of
Table 7. Slope estimation of the analysed sub-basins.

\begin{tabular}{lccc}
\hline Stations & Mean (\%) & Maximum $(\%)$ & Area $\left(\mathrm{km}^{2}\right)$ \\
\hline Rio Branco & 2.0 & 13.6 & 23,500 \\
Seringal da Caridade & 2.4 & 21.2 & 63,100 \\
Seringal Fortaleza & 1.9 & 21.2 & 154,000 \\
Lábrea & 1.8 & 44.4 & 226,000
\end{tabular}

Source: SRTM data, v4. 90m.

watersheds by reducing the effect of scale (Araújo and Knight 2005, Jiongxin and Yunxia 2005).

The estimated suspended solid-specific discharges of the hydrometric stations in the Purus River basin were obtained according to Eq. (4), being presented by Table 6 .

Seringal da Caridade station had the highest estimated suspended solid-specific discharge analysed for this study, from 2000 to 2010 (due to the compatibility of rainfall data, daily flows and solid discharge). The suspended sediment production in this sub-basin reaches an average of $48.2 \mathrm{t} \mathrm{km}^{2}$ month $^{-1}$, almost twice as high (91\%) than the second highest value (Seringal Fortaleza station).

The sediment production process is complex and begins by precipitation events, depending on the classes and characteristics of ground cover, among others. However, it is the river strand that the process sets in, because in association with soil function and reliefs, the runoff will have greater strength (shear stress) to loosen aggregates and carry them to places more downstream, until that flow connects to the river channels.

In other words the sediment yield in a river basin is directly related to the biotic and abiotic characteristics in the environment (e.g. vegetation and pedogeomorphology) as well as the rainfall intensities active in it. This reflects in a natural process which wear the landscape (Tricart 1977), but can be intensified by human action (Ab'saber 1969).

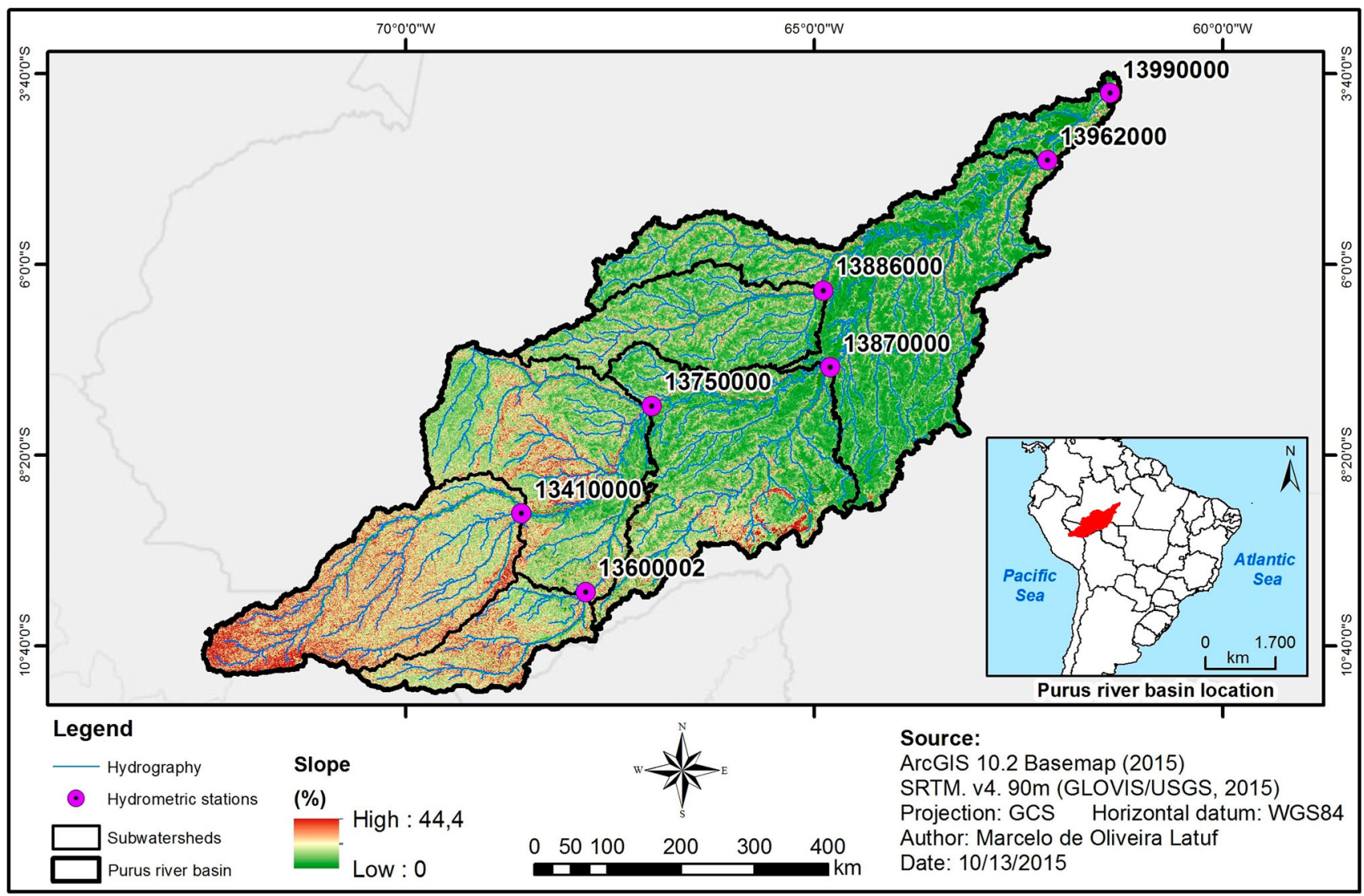

Figure 13. Slope of the Purus River sub-basins. 
Table 8. Monthly specific suspended sediment yield to the Purus River $\left(\mathrm{t} \mathrm{km}{ }^{2}\right.$ month $^{-1}$ ).

\begin{tabular}{lcc}
\hline Month & $R^{2}$ & Equation \\
\hline January & 0.9620 & $-0.0006 x+145.65$ \\
February & 0.9609 & $-0.0007 x+186.07$ \\
March & 0.9997 & $-0.0006 x+160.28$ \\
April & 0.9852 & $-0.0003 x+109.44$ \\
May & 0.6937 & $3 \mathrm{E}-05 x+20.759$ \\
June & 0.9262 & $3 \mathrm{E}-05 x+2.6256$ \\
July & 0.9963 & $8 \mathrm{E}-06 x+0.8033$ \\
August & 0.9608 & $2 \mathrm{E}-06 x+0.5536$ \\
September & 0.9975 & $2 \mathrm{E}-06 x+0.2925$ \\
October & 0.8372 & $-8 \mathrm{E}-06 x+2.5187$ \\
November & 0.8987 & $-9 \mathrm{E}-05 x+21.32$ \\
December & 0.9393 & $-0.0003 x+75.239$ \\
\hline
\end{tabular}

Collaborating with the analysis of the reason for the increased suspended-specific sediment production being located in a sub-basin, with a little change by anthropogenic deforestation, Table 7 presents data on the estimated slope of the analysed sub-basins.

The Seringal da Caridade sub-basin has the highest average slope of all analysed sub-basins (2.4\%), as well as the most representative area, as displayed in Figure 13. It is noted that the sub-basin Lábrea station contains the largest slope of the Purus River basin (44\%), but in a little representative area, which did not influence on its highest suspended sedimentspecific production (average of $13.9 \mathrm{t} \mathrm{km}^{2}$ month ${ }^{-1}$ ).

It is noteworthy that significant territorial portion of larger slope areas in the basin of the Purus River, located in Acre State, are currently protected areas (either full protection or sustainable use). This brings a safety regarding the control over the use and land cover in those areas, due to the government policies, because otherwise, it is estimated that the suspended sediments-specific production would increase significantly.

Furthermore, there is the need for effective watershed planning with a transnational perspective, especially when it comes to international relations with neighbouring countries, as the largest steepness found in the Seringal da Caridade basin is in territory belonging to Peru.

Equally important are the joint mobilizations between Brazil, Peru and Bolivia in the region since 1999, when initiatives by NGOs established the MAP region (Madre de
Dios/Peru, Acre/Brazil and Pando/Bolivia) to improve government actions discussions, seeking improvements in several sectors, mainly aimed at environmental planning and management (Mendoza et al. 2005).

On the other hand, depending on the hydrometric stations located in the main channel of the Purus River basin, the contribution of monthly suspended-specific sediment can be estimated, as shown in Table 8 , in which the independent variable $(X)$ is the drained area interested point (as long as it is in the Purus River depth).

Guided by studies conducted by Owens and Slaymaker (1992), about the relation between sediment yield and the area of contribution in various basins throughout the world, this study propose the suspended-specific sediment yield model $\left(\mathrm{t} \mathrm{km}^{2}\right.$ year $\left.^{-1}\right)$ for the Purus River (Figure 14). It should be noted that this estimate is only valid for the Purus River.

Accordingly, it can be estimated from the adjustment equation, the specific contribution of suspended sediments due to the drainage area $\left(\mathrm{km}^{2}\right)$ to anywhere in the Purus river. However, it should be noted that this adjustment was based on analysis of three hydrometric stations (Seringal da Caridade, Seringal Fortaleza and Lábrea stations), due to the unavailability data (flow or suspended sediments) to the other stations in the Purus River.

So, this equation fills a momentary gap in the possibility of monitoring suspended sediment in the Purus River, but on the other hand, we recognize the need to move with respect to the data analysis for the other hydrometric stations.

\section{Final considerations}

This study aimed to carry out an assessment of the SSD in the Purus River basin, analysing issues related to the deforestation dynamics and rainfall.

It was detected, by analysis in series, historical deforestation data obtained by PRODES/INPE program for the period 2000-2014, that the deforestation rate in the basin reduced significantly, but a new challenge to Brazilian public administrations of the various spheres has been identified, with the deforested area increased relative to mapped polygons. This phenomenon also happens for all the sub-basins hydrometric stations analysed.

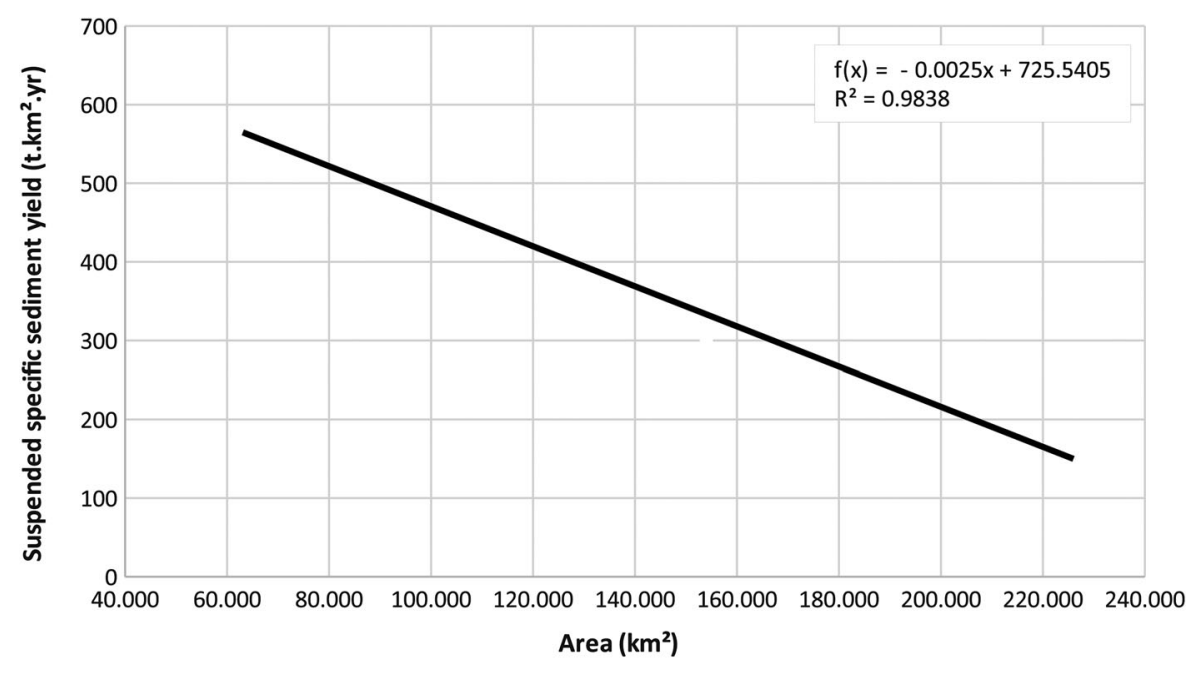

_ Proposal model for suspended specific sediment yield for Purus River

Figure 14. Suspended-specific sediment yield model for Purus River. 
Regarding rainfall dynamics, a trend of increased average rainfall was detected for all hydrometric station contributed areas in the Purus River basin analysed by this study.

Given this situation, associating the deforestation advancement with the increased average rainfall, it appears that due to the reduction of soil protection against the effects of kinetic energy of raindrops by the canopy and understory, that erosion processes (laminar and linear) will have a force greater than one's natural dynamics, leading to soil loss and reduction of natural soil fertility and contributing to siltation of river channels, with smaller reduction in some areas, providing a higher probability of overflowing the river channel, causing flooding.

This fact was proven by the increased flow coefficient trends presented by hydrometric stations examined in this study. Thus, two sub-basins (Rio Branco and Lábrea) showed an increased trend in suspended solid discharge from 2000 to 2010. Those trends were not identified in the Seringal da Caridade e Seringal Fortaleza stations owing to the scale effect.

The diagnosis and comparisons between sub-basins were made, relying on estimated suspended sediment production, highlighting the sub-basins of Lábrea and Rio Branco stations, the latter located in the most modified landscape.

They were also prepared estimates and statistical models for the suspended sediment-specific production on a monthly basis, for the main channel of the basin (Purus). There was also the proposal of a statistical model, annual basis for the prediction of suspended sediment-specific production, in an initial proposal for the inference of such parameter.

Thus, it is expected that this study may have begun filling a gap, with respect to knowledge and understanding of suspended sediment dynamics in the Purus River basin, aiming to help and give subsidies to the planning and management of water resources in that basin.

Being a cross-border basin between Brazil, Peru and Bolivia, actions with the involvement of agencies and public and private organizations, educational and research institutions, and civil society via organization MAP, of all countries involved, could intensify action planning and shared management, with the aim of environmental preservation and maintaining the quality of life for the people of that basin.

Although, without data or data in a few spots and unevenly distributed, with incipient or failed historical series, there is no way to have knowledge of the extent of the sedimentary dynamics of that basin, leaving those countries to establish cooperation agreements, aimed at expanding the hydrometeorological monitoring network, via automatic and conventional stations.

The Brazilian hydrometric network management responsibility is in charge of the National Water Agency (ANA), according to Law Decree No. 9984/2000, which is related to the ANA creation and its responsibilities.

Historically, there is a deficiency in data records in Brazil about the hydrometric sediment dynamics. ANA increases permanently the data collection network; however, for technical and practical questions, the hydrometric sediment network still remains on a hierarchically inferior position compared to quote, flow and precipitation data. This context is also applied to the Purus River basin which has few hydrometric sediment monitoring points, taking into account the extent and diversity of environments of that watershed.

\section{Acknowledgements}

The authors would like to thank the support to collect and process the rainfall and deforestation data to Ana Carolina Cardoso Silva, Hanna Sayuri de Souza Chinen and Viviane Costa Bueno, Geography students of the Federal University of Alfenas (UNIFAL-MG). We also would like to thank the reviewers to dedicate your time to improve our paper with some important suggestions.

\section{Disclosure statement}

No potential conflict of interest was reported by the authors.

\section{References}

Ab'saber, A.N., 1969. A geomorphological concept to serve to quaternary researches, vol. 18. São Paulo: Brazilian Geomorphological Union, IGEOG-USP, 01-23. (in Portuguese).

Acre, 2006. Acre state government. Economical-ecological zoning: stage II. Scale 1:250.000. Rio Branco: Secretary of State of the Environment (SEMA). (in Portuguese).

Acre, 2015. Acre state news website. Available from: www.agencia.ac. gov.br. [Accessed: 3 October 2015].

Amaral, E.F., 2007. Environment stratification to environmental manage and knowledge transfer, Acre State, Southwestern Amazonia. Viçosa: Federal University of Viçosa. Thesis (PhD) (in Portuguese).

Ana, 2015. Brazilian National Water Agency. Hidroweb system. Available from: www.hidroweb.ana.gov.br. [Accessed: 5 September 2015] (in Portuguese).

Araújo, J.C. and Knight, D.W., 2005. A review of the measurement of sediment yield in different scales. REM: Mining School Journal, Ouro Preto, 58 (3), 257-265, jul. set.

Becker, B.K., 1997. Amazon. 5th ed. São Paulo: Ática Publisher, 112 p. (in Portuguese).

Bertalanffy, L.V., 1975. General systems theory. Petrópolis: Vozes Publisher, 351. (in Portuguese).

Carvalho, N.O., 1994. Applied hydrosedimentology. Rio de Janeiro: CPRM, 372. (in Portuguese).

Carvalho, N.O., et al., 2000. Sedimentometric practical guide. Brasília: ANEEL, 154. (in Portuguese).

Chandless, W. 1866. Ascent of the River Purús. Journal of Royal Geographical Society of London, 36, 86-118.

Crawford, C.G., 1991. Estimation of suspended-sediment rating curves and mean suspended-sediment loads. Journal of Hydrology, 129, 331-348.

Fisch, G., Marengo, J.A., and Nobre, C.A., 2015. Amazon climate. Available from: http://climanalise.cptec.inpe.br/ rclimanl/boletim/ cliesp10a/fish.html. [Accessed 2 October 2015] (in Portuguese).

Frailey, C.D., et al., 1988. A proposed Pleistocene/Holocene lake in the Amazon basin and its significance to Amazonian geology and biogeography. Acta Amazônica, 18 (3-4), 119-143.

Guerra, A.J.T., 1999. The initial of erosive process. Soils erosion and conservancy. Rio de Janeiro: Bertrand Brasil Publisher, 17-55 (in Portuguese).

Horowitz, A.J., 2003. An evaluation of sediment rating curves for estimating suspended sediment concentrations for subsequent flux calculations. Hydrological Process, 17, 3387-3409.

Ibge., 2015. Brazilian Institute of Geography and Statistics. SIRGAS2000 and WGS84 analogy. Available from: http://www.ibge.gov.br/home/ geociencias/geodesia/pmrg/faq.shtm\#11. [Accessed 7 October 2015] (in Portuguese).

Jansson, M.B., 1996. Estimating a sediment rating curve of the Reventazón river at Palomo using logged mean loads within discharge classes. Journal of Hydrology, 183, 227-241.

Jiongxin, X. and Yunxia, Y., 2005. Scale effects on specific sediment yield in the Yellow River basin and geomorphological explanations. Journal of Hydrology, 307, 219-232.

Latrubesse, E. and Ramanell, C., 1994. A Climatic Model for Southwestern Amazonia at last glacial times. Quaternary International, 21, 163-169.

Latuf, M.O., 2011. Hydrological modelling applied to water resources planning and management for Acre River Presidente Prudente: FCT/UNESP. PhD thesis. (in Portuguese). 
Machado, P.J.O. and Torres, F.T.P., 2011. Introduction of climatology São Paulo: Cengage Learning. (in Portuguese).

Marques, F.A. and Silva, D.D., 2007. Pixel based analysis for morphometric variables after SRTM treatment data. Florianópolis: Annals XIII SBSR, 3445-3452 (in Portuguese).

Mendiondo, E.M. and Tucci, C.E.M., 1997. Hydrological scales I: concepts. Brazilian Water Resources Journal, 2 (2), 1-21. Jul/Dec, 2144 (in Portuguese).

Mendoza, E.R.H., et al., 2005. The MAP an acronym of effort and collaboration in the region of South-Western Amazon. In: M. Coy and G. Kohlhepp, eds. Sustainable Amazon: sustainable development between public politics, innovate strategies and local experiences. Garamond: Tübinger, Alemanha, 97-110 (in Portuguese).

Merten, G.H. and Poleto, C., 2006. Monitoring network and samples collection. In: G.H. Merten and C. Poleto, eds. Sediment's quality. Porto Alegre: ABRH, 1-397 (in Portuguese).

Nepstad, D.C., et al., 2008. Interactions among Amazon land use, forests and climate: prospects for a near-term forest tipping point. Philosophical Transactions of the Royal Society B: Biological Sciences, 363, 1737-1746.

Owens, P. and Slaymaker, O., 1992. Late Holocene sediment yields in small alpine and subalpine drainage basins. British Columbia, IASH Publications No. 209, 147-154.

Peel, M.C., Finlayson, B.L., and Mcmahon, T.A., 2007. Updated world map of the Köppen-Geiger climate classification. Hydrology and Earth System Sciences, 11, 1633-1644, doi:10.5194/hess-11-1633-2007
Prodes Digital, 2015. National Institute for Space Research (INPE). Available from: http://www.obt.inpe.br/prodes/index.php. [Accessed 28 September 2015] (in Portuguese).

Ramos, A.M., Santos, L.A.R., and Fortes, L.T.G., 2009. Brazilian climatological normals: 1961-1990. Brasília: INMET (in Portuguese).

Rodriguez, R.D.G., 2004. Methodology for demand estimate and water availability: case study of Paracatu River Basin. Viçosa: DEA/UFV. (Master Degree) (in Portuguese).

Santos, E.S., Motenegro, A.A.A., and Silva Junior, V.P., 2012. Flow discharge and sediment transport analysis at representative Alto Ipanema's catchment. Annals of X Water Resources Simposium of Nordeste. João Pessoa: ABRH (in Portuguese).

Silva, J.R., 2015. TRMM guide of procedures treatment. Goiânia: LAPIG/ UFG (in Portuguese).

Silva, Y.J.A.B., Oliveira Silva, M.D.R., and Cantalice, J.R.B., 2010 Suspended sediment yield on the Ipojuca River Basin-Porto de Suape. Annals of IX National Sediment Engineering Meeting. Brasília: ABRH (in Portuguese).

Tricart, J., 1957. The evolution of the slopes. The Geographic Information, 21, 108-115. (in French).

Tricart, J., 1977. Ecodymanics. Environmental natural resources. Rio de Janeiro: IBGE. (in Portuguese).

Tucci, C.E.M., 2009. Hydrology: science and application. 4th ed. Porto Alegre: UFRGS/ABRH (in Portuguese)

Walling, D.E., 1977. Assessing the accuracy of suspended sediment rating curves for a small basin. Water Resources Research, 13 (3), 1-8. 